University of Nebraska - Lincoln

DigitalCommons@University of Nebraska - Lincoln

\title{
Rhinocyllus conicus: Initial Evaluation and Subsequent Ecological Impacts in North America
}

A. Gassmann

CABI Bioscience Centre Switzerland

Svata M. Louda

University of Nebraska - Lincoln, slouda1@unl.edu

Follow this and additional works at: https://digitalcommons.unl.edu/bioscifacpub

Part of the Life Sciences Commons

Gassmann, A. and Louda, Svata M., "Rhinocyllus conicus: Initial Evaluation and Subsequent Ecological Impacts in North America" (2001). Faculty Publications in the Biological Sciences. 100.

https://digitalcommons.unl.edu/bioscifacpub/100

This Article is brought to you for free and open access by the Papers in the Biological Sciences at DigitalCommons@University of Nebraska - Lincoln. It has been accepted for inclusion in Faculty Publications in the Biological Sciences by an authorized administrator of DigitalCommons@University of Nebraska - Lincoln. 


\title{
Rhinocyllus conicus: Initial Evaluation and Subsequent Ecological Impacts in North America
}

\author{
A. Gassmann ${ }^{1}$ and S.M. Louda ${ }^{2}$ \\ ${ }^{1} \mathrm{CABI}$ Bioscience Centre Switzerland, $\mathrm{CH}-2800$ Delémont, \\ Switzerland; ${ }^{2}$ School of Biological Sciences, University of \\ Nebraska, Lincoln, NE 68588-0118, USA
}

\section{Abstract}

Renewed debate over the risk of non-target effects in biological control reflects, in part, the recent quantification of direct and indirect ecological effects of the flowerhead weevil, Rhinocyllus conicus Fröl, in North America. To help resolve the issue, we review the published data for $R$. conicus from both Europe and North America: pre-release (1961-1968), post-release (1969-1985) and more recent (1986-1999). Our aim was to determine the extent to which host range expansion on to native North American species, and the associated ecological effects, were predicted or predictable. Our overall conclusion is that more was known than is generally realized, yet more information would have been required to complete the initial assessment of ecological consequences. Three important points emerge. First, the potential effect of $R$. conicus on native North American species was not a major element of the testing programme. Second, the host range expansion observed is consistent with the pre-release and early post-release data, and so was predictable, if not predicted. The pre- and early post-release data showed that $R$. conicus could feed and develop on multiple Cirsium species, including two North American species. Third, we found that the studies needed to quantify the likely magnitude of feeding by $R$. conicus on North American Cirsium species, and thus the ecological consequences of that feeding, were not done. Instead, inferential arguments were used to suggest that any feeding by $R$. conicus on North American species would not be substantial. We conclude that there were sufficient data, which suggested that North American Cirsium species would be acceptable 
host species, to have warranted further testing to define and quantify the potential ecological side-effects of introducing $R$. conicus to North America. Contemporary concerns should now mandate such tests.

\section{Introduction}

The risks associated with the practice of biological control, especially the potential for harmful ecological effects on non-targeted native species, are being debated again (see Secord and Kareiva, 1996; Simberloff and Stiling, 1996, 1998; Frank, 1998; Thomas and Willis, 1998). The issue is not new (e.g. Simberloff, 1981, 1992; Howarth, 1983, 1991). In fact, the importance and the need of doing more quantitative evaluations of potential risk to non-target native species was argued by several biological control practitioners over 15 years ago (Andres, 1985; Pemberton, 1985a,b; Turner, 1985). Several countries, such as Australia and New Zealand, have instituted a clear legislative process to identify risks, to involve all affected parties and to ensure that non-target impacts are minimized (New Zealand Government, 1994; Withers et al., 2000).

In this chapter, we will review the evidence available to evaluate the specific case of the introduction of Rhinocyllus conicus Fröl. (Fig. 8.1) into North America. This Eurasian weevil was released for the biological control of true thistles, especially those in the genus Carduus. Recent evidence that

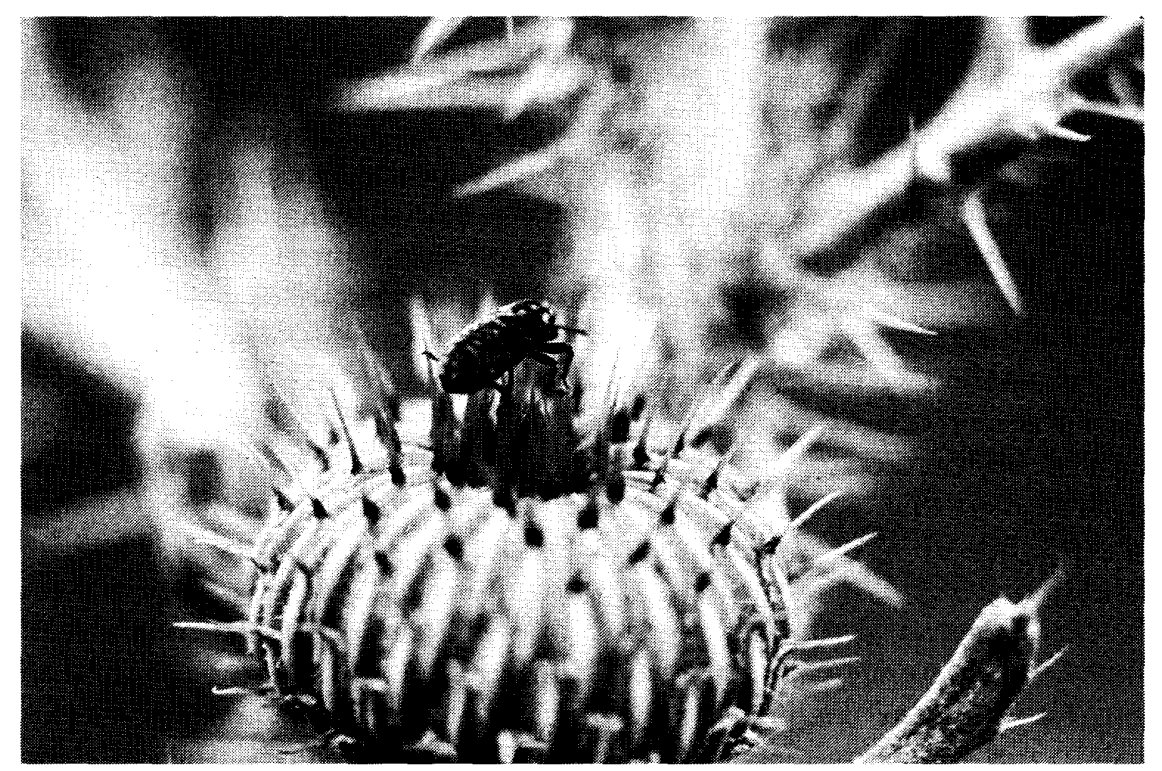

Fig. 8.1. Rhinocyllus conicus on Platte thistle (Cirsium canescens Nutt.) at Arapaho Prairie, Arthur County, Nebraska, USA. 
$R$. conicus populations are increasing in nature preserves and National Parks in the central USA (Louda et al., 1997, 1998; Louda, 1998), and that these populations are having a significant impact on native plant and insect species within the preserves (Louda et al., 1997; Louda, 2000a; Louda and Arnett, 2000), has rekindled earlier apprehensions about the environmental safety of classical biological control (Howarth, 1991; Secord and Kareiva, 1996; Simberloff and Stiling, 1996).

Specifically, we will examine the evidence developed on this insect and its host plant interactions in Europe before, and in the 15 years after, its release in North America. Then, we will summarize the more recent findings. Thus, our purpose is to determine the extent to which the host range expansion on to native North American Cirsium species, and the ecological effects recently associated with this expansion, were predicted or predictable from the published data used to evaluate economic and environmental risk. Our overall conclusion for this case is that more was known than is generally realized, and yet more information would have been required to effectively assess potential ecological consequences.

The common name 'thistle' is customarily applied to species in the Tribe Cardueae of the Asteraceae (Compositae), and the term 'true thistle' is sometimes used to refer to the spiny species of the Subtribe Carduinae. Some ten different 'true thistle' species in four genera of western Palaearctic origin (Carduus, Cirsium, Silybum and Onopordum) have been accidentally introduced into North America, Australia and New Zealand (Julien and Griffiths, 1998). No native Carduus species occur in North America and most indigenous Nearctic true thistles belong to the genus Cirsium. The Carduus nutans group is taxonomically difficult, and it includes several species or subspecies (Desrochers et al., 1988). In this chapter, we use C. nutans $\mathrm{L}$. to refer to all of the taxa in this complex group.

In North America, the weediness of exotic true thistles was viewed as an agronomic problem (e.g. Dunn, 1976; McCarty, 1978). So, both the US Department of Agriculture (in 1959) and the Canadian Department of Agriculture (in 1961) initiated biological control programmes against exotic thistles, starting with broad surveys of the insects and pathogens on the Cardueae in Europe (Zwölfer, 1965; Boldt, 1978; Dunn, 1978). Between 1961 and 1966, 2283 populations or stands of 16 genera in the tribe, including 1354 in the Subtribe Carduinae, were surveyed from western France to eastern Austria, and from southern Germany to northern Italy and northern former Yugoslavia (Zwölfer, 1965). Over 120 species of insects were associated with true thistles in the genera Carduus, Cirsium, Silybum and Onopordum in the western portion of their indigenous Eurasian range (Zwölfer, 1965; Redfern, 1983). Boldt (1978) reported that some 40 insects were endophytic on C. nutans in Italy. On the basis of the surveys and early tests, $R$. conicus was selected as the first agent to be released in North America for the biological control of exotic thistles, especially those in the genus Carduus. Weevils, collected in the upper Rhine Valley 
in eastern France, were first released in Canada in July 1968 on musk (nodding) thistle (C. nutans) near Regina, Saskatchewan, and on plumeless thistle (Carduus acanthoides L.) near Belleville, Ontario (Harris and Zwölfer, 1971). In 1969, introductions from eastern France began in the United States, with releases in California, Montana, Nebraska and Virginia (Hawkes et al., 1972; Kok, 1974; Kok and Surles, 1975; Rees, 1977, 1978, 1982, 1991; McCarty, 1978; Surles and Kok, 1978; McCarty and Lamp, 1982). In Nebraska, weevils from Mulhouse, France, and possibly some from Rome, Italy, were released in 1969 and between 1972 and 1974 on C. nutans near Lincoln and Grand Island (McCarty, 1978; L.A. Andres, unpublished results). The weevil was then actively redistributed in southern and eastern Nebraska (McCarty and Lamp, 1982). Redistribution of $R$. conicus in the United States continues (e.g. Boldt and Jackman, 1993; Buntin et al., 1993).

The history of research on R. conicus in Europe and North America can be divided into three periods, including the pre-release period of research in Europe (1961-1968), the early post-release period (1969-1985) and the more recent period of research (1986-1999). After reviewing the natural history of $R$. conicus, we will summarize the findings relevant to evaluation and prediction of post-introduction performance from each of these periods. We will then address the general question of whether the state of knowledge at pre-release and early post-release was sufficient to predict both the occurrence of feeding and the magnitude of ecological impact by $R$. conicus on native thistles and their adapted floral insects. We contend that such retrospective studies can be used to evaluate and improve future efforts in biological control.

\section{Natural history of Rhinocyllus}

The indigenous geographical distribution of $R$. conicus includes central and southern Europe and North Africa (Hoffmann, 1954), as well as Asia Minor (Schaufuss, 1915). Preferred habitats of thistles in Europe, according to Zwölfer (1964), are in dry and warm localities below elevations of $600 \mathrm{~m}$. Mating and oviposition activity occur in spring and early summer, following adult emergence from overwintering in litter and sheltered sites and a pre-oviposition feeding period of varying length. Eggs are laid externally, either individually or in small clusters, on the lower surface of the involucral bracts of young flowerheads (Rees, 1977, 1982; Zwölfer and Harris, 1984). The life cycle is well documented. Larvae feed on the florets, the developing receptacle, callus tissue produced near the feeding site (Shorthouse and Lalonde, 1984), and sometimes into the peduncle under the head (Zwölfer and Harris, 1984). At the end of the fourth instar, the larva forms an ovoid cell with hard, frass-packed, black walls and pupates (Shorthouse and Lalonde, 1984; Zwölfer and Harris, 1984). Development, 
from egg to teneral adult, took 45-55 days in the Swiss Jura (Zwölfer and Harris, 1984) and 39-62 days in the Gallatin Valley, Montana, USA (Rees, 1982). Teneral adults usually remain within the pupation cells for several weeks before dispersing to find overwintering sites (Zwölfer and Harris, 1984). The number of generations per year can vary, from one in the Apennine Mountains of Italy (Mellini, 1951) and southern Europe (Aeschlimann, 1999), to a partial second generation in the upper Rhine Valley and eastern Austria in central Europe (Zwölfer, 1967).

In Europe, $R$. conicus overlaps with a large number of floral herbivores (Zwölfer, 1965) that may cause substantial mortality (Zwölfer, 1978, 1979). For example, in flowerheads with either Urophora solstitialis L. (Tephritidae) or Larinus sturnus Schall. (Curculionidae), R. conicus mortality averaged 70-90\% (Zwölfer, 1978; Zwölfer and Harris, 1984). In North America, larval survivorship is strongly density-dependent (Surles et al., 1975; Rees, 1977; Dowd and Kok, 1981a; Goeden and Ricker, 1985), suggesting that intraspecific competition can cause larval mortality $(>80 \%)$ within heavily infested inflorescences.

The natural enemy complex is extensive in both Europe and North America. In Europe, Zwölfer and Harris (1984) listed six larval and pupal parasites, plus an egg parasitoid (Mellini, 1951). Parasitism levels in Europe were high, especially by Bracon sp. (43-71\%), Bracon urinator L. $(40-50 \%)$ and Exeristes roborator F. (13-43\%). Natural enemies reported in North America include: parasitoids (1 adult, 10 larval-pupal), predators (a reduviid, a neuropteran, salticid and thomisid spiders) and parasites (a mite, two bacteria and a fungus) (Goeden and Ricker, 1977, 1978; Dowd and Kok, 1981b). Reported levels of parasitism in the USA are very low (<3\%) (Surles, 1974; Surles et al., 1975; Goeden and Ricker, 1977; Rees, 1977; Puttler et al., 1978; Dowd and Kok, 1981a, 1982, 1983; Smith and Kok, 1983). Finally, some intra-guild predation occurs in Europe. Two lepidopterans that develop on floral tissues and achenes within $C$. nutans flowerheads (Pyralidae: Homoeosoma nebulellum $\mathrm{Hb}$., $\mathrm{H}$. binaevellum $\mathrm{Hb}$.) reportedly also feed on any insect larvae that they encounter, including those of $R$. conicus (Zwölfer, 1978). In North America, related lepidopteran larvae (Homoeosoma spp.) occur within flowerheads of native Cirsium species (Lamp and McCarty, 1981; Louda and Potvin, 1995; G. Balogh, personal communication). Rees $(1977,1978)$ found no evidence of feeding by Homoeosoma electellum (Hulst.) on $R$. conicus in Montana, but no direct test has been done.

\section{Pre-release studies in Europe (1961-1968)}

Study of $R$. conicus as a potential biological control agent for exotic thistles in North America, particularly Carduus species, included both field studies of occurrence and host use and laboratory studies of adult behaviour and 
larval performance. Zwölfer and Harris (1984) synthesized most of the results for $R$. conicus available before 1984 .

\section{Early field studies}

Field collection records of $R$. conicus in Europe (Table 8.1) show that eggs or larvae of $R$. conicus were found on five out of nine Carduus species (55.6\%) and two out of 16 Cirsium species (12.5\%), as well as on Silybum marianum (L.) Gaertner and Onopordum acanthium L. (Zwölfer, 1967). Adults were also found on Carduus sanctae-balmae Lois, at Toulon in southern France, and on Cirsium vulgare Ten., at Nantes in western France and at Châteauroux in central France, but not on $C$. vulgare in eastern France or in the Rhine Valley. $R$. conicus larvae and adults were found on $C$. nutans everywhere except in southern France and north-eastern Spain. Other host plants in the literature included Galactites tomentosa Moench and four more Cirsium species: Cirsium eriophorum (L.) Scop., Cirsium canum (L.) All., Cirsium anglicum Lob. and Cirsium chrysacanthum Ball. These literature records, however, could not be confirmed in the early surveys (Zwölfer, 1965; Zwölfer and Harris, 1984).

The field records for Europe suggested a clear preference of $R$. conicus for Carduus species over other accepted plant species. Zwölfer (1967) pointed this out:

The genus Carduus is by far preferred over the host genera Cirsium, Silybum, or Onopordum. The genus Cirsium has been investigated much more intensively than the genus Carduus, but nevertheless $75 \%$ of the records of adults and $80 \%$ of the records of larvae of $R$. conicus originate from Carduus species.

$R$. conicus was observed on three out of 16 Cirsium species investigated. The percentage of samples containing eggs or larvae of $R$. conicus varied from 20 to $60 \%$ within the genus Carduus, below $5 \%$ in the genus Cirsium, and below $10 \%$ in the genera Silybum and Onopordum. Unlike for Larinus spp., no evidence of intraspecific differentiation was observed. So, Zwölfer (1967) suggested that regional differences in host plant association of $R$. conicus could be related to host preference and phenology.

Population phenology of $R$. conicus, initiated by adult emergence from overwintering sites, varies with latitude and elevation within Europe and the Mediterranean. For example, in the upper Rhine Valley in the north, Zwölfer $(1964,1967)$ found that $R$. conicus adults were active from the first half of May, when they were abundant, until August. Larvae were found in flowerheads from late May until August, and pupae occurred from mid-July to September (Zwölfer, 1964, 1967; Zwölfer and Harris, 1984). A partial second generation sometimes occurred for individuals that completed development early, when day length was greater than $16 \mathrm{~h}$ (Zwölfer, 1967; Zwölfer and Harris, 1984). Additionally, in the Apennine Mountains north 
of Florence, Mellini (1951) observed a relatively late onset of all stages: oviposition in early July, larval development in July/August and pupation in late August. In the Mediterranean climate region, for example near Toulon and Orange in southern France and Gerona in northern Spain, Zwölfer (1967) found over-wintered $R$. conicus adults emerging very early, from mid-April, and eggs were found from early May. In summary, $R$. conicus in the Mediterranean climatic area were active several weeks ahead of those in the more continental areas or higher elevations, and they were reported to have a shorter activity period.

\section{Early laboratory studies of host acceptance, preference and performance}

The plant species tested in the screening trials included primarily cultivated plants, agricultural crops and horticultural species, plus European thistles (Zwölfer, 1964, 1967, 1969; Zwölfer and Harris, 1984). All the tests were made with field-collected adults originating from $C$. nutans from eastern France. In no-choice feeding tests, where adult weevils were offered leaves of a potential host plant, no feeding occurred on the cultivated non-Astereae, but 12 of the 16 European species of Carduinae offered were fed upon. One North American Cirsium (Cirsium undulatum Spreng.) was screened in one small adult feeding trial in Canada $(n=$ five weevils). The leaves of this species were accepted, but only at the 'slight and inconsistent feeding' level (Zwölfer, 1967), the same level as European Carduus tenuiflorus Curtis, S. marianum and O. acanthium (Zwölfer and Harris, 1984). Interestingly, the five weevils in this trial on C. undulatum died more rapidly than did those on the leaves of other thistles tested (Zwölfer, 1967; Zwölfer and Harris, 1984).

Some feeding was noted in preference (i.e. 'choice') tests, where adult weevils were offered leaves of both $C$. nutans and another plant in the Tribe Cardueae, i.e. Carlina vulgaris L., Carthamus tinctorius L. and Cnicus benedictus L., as well as 12 of 14 species in the Subtribe Carduinae (Zwölfer, 1964). Among the Carduinae, two results are striking. First, the preference for two $(16.7 \%$ ) of the 12 species (Carduus crispus L., Cirsium acaule (L.) Scop.) was actually greater than that for $C$. nutans. Second, the thistles fell into two groups. The highly preferred group included (in rank order): C. crispus, C. acaule, C. nutans and Cirsium vulgare. The less preferred group included (in rank order): Cirsium arvense (L.) Scop., Cirsium rivulare (Jacq.) All., Cirsium palustre (L.) Scop., Carduus personata (L.) Jacq., S. marianum, Cirsium oleraceum (L.) Scop., Carduus tenuiflorus and O. acanthium (Zwölfer, 1964). These two groups are clearly not defined by host plant genus.

In oviposition and larval development tests, the data included records of eggs laid in laboratory feeding trials on leaves, and a no-choice field test of oviposition and development. The latter test was done in the garden at Delémont, Switzerland, on four of the eight European thistles with 
Table 8.1. Field records of Rhinocyllus conicus (modified from Zwölfer, 1965, 1967; Zwölfer and Harris, 1984).

\begin{tabular}{|c|c|c|c|c|c|c|}
\hline & \multicolumn{3}{|c|}{$1961-1966$} & \multicolumn{3}{|c|}{$1961-1982$} \\
\hline & $\begin{array}{l}\text { Populations } \\
\text { sampled }\end{array}$ & $\begin{array}{l}\% \text { samples } \\
\text { with larvae }\end{array}$ & $\begin{array}{l}\% \text { samples } \\
\text { with adults }\end{array}$ & $\begin{array}{l}\text { Populations } \\
\text { sampled }\end{array}$ & $\begin{array}{l}\% \text { samples } \\
\text { with larvae }\end{array}$ & $\begin{array}{c}\% \text { samples } \\
\text { with adults }\end{array}$ \\
\hline \multicolumn{7}{|l|}{ Echinopinae } \\
\hline Echinops (4 spp.) & 25 & 0 & 0 & 41 & 0 & 0 \\
\hline \multicolumn{7}{|l|}{ Carlinae } \\
\hline Carlina (3 spp.) & 85 & 0 & 0 & 158 & 0 & 0 \\
\hline Xeranthemum (1 sp.) & 5 & 0 & 0 & 7 & 0 & 0 \\
\hline \multicolumn{7}{|l|}{ Centaureinae } \\
\hline Serratula (1 sp.) & 16 & 0 & 0 & 17 & 0 & 0 \\
\hline Centaurea (17 spp.) & 750 & 0 & 0 & 950 & 0 & 0 \\
\hline Microlonchus (1 sp.) & 8 & 0 & 0 & 11 & 0 & 0 \\
\hline Crupina (2 spp.) & 5 & 0 & 0 & 6 & 0 & 0 \\
\hline Leuzea (1 sp.) & 5 & 0 & 0 & 9 & 0 & 0 \\
\hline Carthamus (1 sp.) & 30 & 0 & 0 & 47 & 0 & 0 \\
\hline
\end{tabular}




\section{Carduinae}

\begin{tabular}{|c|c|c|c|c|c|c|}
\hline Arctium (4 spp.) & 60 & 0 & 0 & 106 & 0 & 0 \\
\hline Jurinea (1 sp.) & - & - & - & 2 & 0 & 0 \\
\hline Staehelina (1 sp.) & 5 & 0 & 0 & 8 & 0 & 0 \\
\hline Galactites (1 sp.) & 10 & 0 & 0 & 12 & 0 & 0 \\
\hline Carduus nutans & 109 & 57.5 & 60.0 & 157 & 49.0 & 50.3 \\
\hline C. nigrescens & 3 & 33.3 & 100.0 & 3 & 33.3 & 100.0 \\
\hline C. personata & 25 & 33.0 & 38.0 & 28 & 35.7 & 42.9 \\
\hline C. crispus & 20 & 40.0 & 20.0 & 30 & 26.7 & 13.3 \\
\hline C. sanctae-balmae & 6 & 0 & 50.0 & 6 & 0 & 50.0 \\
\hline C. pycnocephalus & 12 & 20.0 & 30.0 & 17 & 23.5 & 35.3 \\
\hline C. acanthoides & 39 & 0 & 0 & 55 & 0 & 3.6 \\
\hline Two other Carduus & 40 & 0 & 0 & 44 & 0 & 0 \\
\hline Cirsium vulgare & 142 & 0 & 0.8 & 225 & 6.2 & 7.1 \\
\hline C. palustre & 47 & 4.0 & 0 & 60 & 3.3 & 0 \\
\hline C. setosum & - & - & - & 3 & 33.3 & 0 \\
\hline C. arvense & 475 & 3.5 & 4.0 & 550 & 2.9 & 3.8 \\
\hline 13 other Cirsium & 300 & 0 & 0 & 356 & 0 & 0 \\
\hline Silybum marianum & 14 & 8.0 & 0 & 23 & 17.4 & 26.1 \\
\hline Cynara scolymus & - & - & 一 & 4 & 0 & 0 \\
\hline Onopordum acanthium & 42 & 5.0 & 10.0 & 47 & 4.2 & 8.5 \\
\hline Two other Onopordum & 5 & 0 & 0 & 19 & 0 & 0 \\
\hline
\end{tabular}

aPercentage of local populations sampled for the presence of larvae or adults of $R$. conicus. 
R. conicus oviposition recorded from the field: Carduus nutans, C. personata, Cirsium arvense and C. palustre. Each of these species supported complete development. Zwölfer (1967) noted that 'The adults emerging from C. arvense and C. palustre were, however, about $10 \%$ smaller than their parents which originated from C. nutans'. Thus, this early screening trial showed that the two European Cirsium species were adequate hosts, even though they were much less preferred than C. nutans in adult feeding trials (Zwölfer, 1964). No oviposition tests or larval development tests were carried out on any North American Cirsium species. Also, no multiplechoice oviposition preference and larval development tests were done to determine the relative ranking of potentially acceptable European or North American thistle species.

In summary, the early trials substantiated that feeding by $R$. conicus was restricted to the Subtribe Carduinae, and they suggested that some species of acceptable thistle host plants were preferred over others. Since none of the agricultural crops and horticultural species tested was used by the weevil, the decision was taken by the Canada Department of Agriculture and the US Department of Agriculture, Agricultural Research Service, to release the weevil on exotic thistles in Canada (C.nutans, C. acanthoides) and in the United States (C. nutans, $S$. marianum). Redistribution of $R$. conicus continued, even though some feeding on non-target Cirsium species was recorded very early and there was "considerable opposition to the introduction to North America of biocontrol agents for thistles on the grounds that they may also damage native Cirsium spp.' (Zwölfer and Harris, 1984).

\section{Early post-release studies (1969-1985)}

After release, studies of the host associations of $R$. conicus in Europe were continued, and studies of the biology and feeding of $R$. conicus on its targeted host plants were done in North America.

\section{Field studies in Europe}

Additional surveys were carried out during 1981 (see Table 8.1). The patterns were consistent with the previous studies, although $R$. conicus adults were also documented on Carduus acanthoides. In addition, the rate of attack recorded on Cirsium vulgare was higher than previously, most likely because sampling increased in south-western France. Occurrence of $R$. conicus on $C$. vulgare was higher in south-western France than in northeastern France, Austria and Germany (Zwölfer and Preiss, 1983). In total, 4 out of 17 Cirsium species (23.5\%), and seven out of nine Carduus species (77.8\%), were recorded as hosts of $R$. conicus during 1981. The phenology of $R$. conicus in North America was quantified and also found to vary with 
latitude, with earlier emergence and activity in the south. In the Gallatin Valley of Montana, USA, overwintered adults were observed aggregating and mating on musk thistle (C. nutans) from mid to late May, and newly emerged adults were found primarily in late July and early August (Rees, 1982). Alternatively, further north, newly emerged adults were observed in late July to early August in southern Ontario, but not until August in Saskatchewan (Harris, 1984).

A major change occurred during this period in the general interpretation of the variation in host plant association of $R$. conicus in the field. Before $R$. conicus was released in Canada in 1968, host preference and possibly host phenology were thought to determine host association (Zwölfer, 1967). However, by 1984, ecotypic differentiation among hostrelated strains ('biotypes') of $R$. conicus was widely, if not universally, accepted as the main determinant of host association (Zwölfer and Harris, 1984). This shift was initiated by Goeden's (1978) observation that the response of $R$. conicus to its host plants in southern California varied. Weevils from Carduus pycnocephalus L. consistently preferred to oviposit on C. pycnocephalus, whereas those from S. marianum preferred S. marianum. Goeden (1978) hypothesized that two 'host races' of $R$. conicus existed in California. He then hypothesized that the earlier attempt to establish $R$. conicus on milk thistle $(S$. marianum) in northern California (Hawkes et al., 1972) had failed because the weevil biotype and weed species were mismatched (Goeden, 1978; Goeden et al., 1985).

In Europe, Goeden's hypothesis stimulated a re-assessment of host records for $R$. conicus. Zwölfer and Preiss (1983), for example, also concluded that $R$. conicus was divided into five 'host race' biotypes: (i) $S$. marianum biotype; (ii) Carduus nutans biotype, also occasionally found on Cirsium spp., which was the most widespread and presumably most ancient biotype, (3) Carduus pycnocephalus - C. tenuiflorus biotype; (iv) Cirsium arvense biotype, which was rare in Europe; and (v) Cirsium vulgare biotype in western France, which was also occasionally found on Carduus nutans. Thus, Zwölfer and Preiss (1983) rejected the weevil - host plant synchrony hypothesis (Zwölfer, 1967) to explain variation in host plant use among regions, and they accepted the innate preference hypothesis instead. They suggested that preference was driven by selection for resource predictability, consistent with the resource concentration hypothesis (Root, 1973), and this determined host plant association and its geographical variation.

At this point, definitive evidence for five clearly differentiated, genetic host races (biotypes) was not available, and some conflicting evidence existed. For example, $R$. conicus from Cirsium vulgare, evaluated in a multiple-choice oviposition test, unexpectedly laid as many eggs on Carduus nutans as they did on Cirsium vulgare (Zwölfer and Preiss, 1983). Also, Jessep (1981) reported that, in New Zealand, $R$. conicus from Canadian Carduus nutans successfully colonized Carduus pycnocephalus, C. acanthoides and $C$. tenuiflorus, as well as $C$. nutans. Moreover, the role of interspecific variation 
in the availability of flowerheads was not evaluated, even though it was known that intraspecific variation in flowerhead size influenced oviposition in both S. marianum and C. vulgare (Zwölfer and Preiss, 1983).

It seems clear that the wide acceptance of host-plant biotypes, and perhaps of resource concentration, as predictive of host use, had a major influence on the interpretation of the data. These perspectives lead to the expectation of insignificant levels of non-target feeding on native North American Cirsium species by R. conicus from C. nutans. The existence of host-plant biotypes in $R$. conicus has been challenged recently (Klein, 1991; Klein and Seitz, 1994).

\section{Laboratory and greenhouse studies of preference and performance in North America}

Kok and his colleagues in Virginia experimentally substantiated the oviposition preference of $R$. conicus from C. nutans in Europe for C. nutans over C. acanthoides in its new environment (Surles and Kok, 1977), as expected. They found that oviposition was better synchronized with $C$. nutans than with C. acanthoides in Virginia. Also, larval crowding decreased survival more in the smaller flowerheads of $C$. acanthoides than in the larger ones of C. nutans (Dowd and Kok, 1981a). Second, Smith and Kok (1985) found that temperature influenced larval development and mortality. The threshold temperature for hatching was $11^{\circ} \mathrm{C}$, and the threshold temperatures for development were between 16 and $20^{\circ} \mathrm{C}$, depending on the stage. Third, Dowd and Kok (1983) documented the influence of plant quality on weevil success. In the greenhouse, weevils developing in flowerheads of musk thistle (C. nutans) plants that were fertilized or well-watered, compared with unfertilized or dry, tended to survive better and they developed into significantly larger adults. Also, phytosterols (especially sitosterol), which are found in highest concentrations in the flowerhead buds, were necessary for complete larval development on artificial diets (Rowe et al., 1985). These studies suggested that preference and synchronization, based on physical conditions and host plant quality, could influence host plant use by $R$. conicus in the field in North America.

\section{Garden plot and field studies in North America}

In Canada, field studies showed that oviposition was concentrated at the beginning of the flowering season. Although egg distribution was aggregated, the larval distribution was even more aggregated, and the degree of aggregation varied significantly among years (Zwölfer and Harris, 1984). Variance-to-mean ratios ranged from 1.84 to 7.99 in pasture and from 1.0 to 11.37 in gravel spoil plots over the first 10 years. Also, the maximum 
number of $R$. conicus maturing in a $C$. nutans head was correlated with its size. Growing conditions again appeared important. For example, the degree of aggregation was inversely correlated with spring soil moisture. Day length affected the development of a second partial generation. Newly developed adults that had emerged early, by mid-June ( $>16 \mathrm{~h}$ light), were observed mating. Finally, a low incidence of parasitism by a wide variety of larval and pupal parasitoids was reported in Canada (Zwölfer and Harris, 1984).

In Virginia, establishment by the $R$. conicus imported from $C$. nutans in eastern France was more successful on $C$. nutans than on $C$. acanthoides (Kok, 1974; Surles et al., 1974; Kok and Surles, 1975), possibly due to synchrony. Total mortality for all immature stages of $R$. conicus on C. nutans, at 11 release sites in Virginia, averaged $68 \%$, ranging from $56.6 \%$ to $95.3 \%$ (Surles et al., 1975). Egg and early instar larval mortality $(58.3 \%$ ) was caused primarily by wind and rain. Late larval and pupal mortality (9.7\%) was caused by parasitism $(3.6 \%)$, larval crowding and unknown factors (Surles et al., 1975). In both 1973 and 1974, weevils reduced the number of viable seeds in the terminal and first lateral heads and total seed production by $35-36 \%$ per C. nutans plant. However, they only reduced viable seed by $0.2 \%$ per $C$. acanthoides plant, due to low infestation rates (Surles et al., 1974; Surles and Kok, 1978). A phenological model of the interaction of R. conicus with C. nutans in Virginia (Smith et al., 1984) demonstrated that temperature could have a major influence on the synchrony of the host plant and weevil, and so on the magnitude of their interaction.

In California, Goeden (1978) and Goeden and Ricker (1977, 1978) found evidence consistent with the host race hypothesis. $R$. conicus, collected from $S$. marianum in southern Italy, established successfully on S. marianum in southern California (1971-1974), even though earlier releases of weevils from $C$. nutans in eastern France had failed to establish on S. marianum in northern California (Hawkes et al., 1972; Goeden, 1978). In 1978, another establishment of the southern Italian form of $R$. conicus was made on $S$. marianum in Fall County, Texas, USA, using weevils from S. marianum in California (Boldt and DeLoach, 1985). Clearly, these observations suggest that genetic variation occurs among populations of $R$. conicus. Interpretation of how that variation is partitioned is now being revised (Klein, 1991; Klein and Seitz, 1994).

In the Gallatin Valley in Montana, USA, Rees $(1977,1978)$ reported that after 5 years $R$. conicus had spread throughout $1280 \mathrm{~km}^{2}$ in the valley, suggesting a rate of spread of up to $19 \mathrm{~km}$ year $^{-1}$. Damage to the primary, terminal flowerheads of $C$. nutans subsp. macrocephalus reduced their seed production, but the later secondary heads were missed (Hodgson and Rees, 1976; Rees, 1978). Interestingly, the length of the oviposition period, when mating weevils were observed, varied between years: 10 days in 1975, 39 days in 1976 (21 May-28 June) and 27 days in 1977 (Rees, 1978). Also, mortality from intraspecific larval competition increased from $23.3 \%$ to $82.5 \%$ as the 
number of $R$. conicus larvae increased from 15.6 to 21.3 per head (Rees, 1977). The sunflower moth, Homoeosoma electellum (Hulst.), was observed to feed within the heads but, unlike the European situation, no evidence of attack on $R$. conicus was found (Rees, 1977). Thus, intraspecific competition probably limited the maximum numbers of larvae that matured per head in Montana, USA.

Feeding by $R$. conicus on North American species of Cirsium was first reported during this period. In Ontario, Canada, Laing and Heels (1978) reported the use of both introduced Cirsium species (C. vulgare, C. arvense) and Maw (cited in Zwölfer and Harris, 1984) reported use of the native Cirsium flodmanii (Rydb.) Arthur, by weevils that were originally collected from C. nutans. In Montana, USA, Rees (1978) reported the use of the native Cirsium undulatum Spreng. (wavyleaf thistle), as well as two introduced Cirsium spp. (C. arvense, C. vulgare), by $R$. conicus shipped from Mulhouse, France, and Rome, Italy, for the control of $C$. nutans. Rees (1978) found that $41 \%$ of the 517 wavyleaf ( $C$. undulatum) thistles examined had $R$. conicus eggs in 1976. Although larvae occurred in the heads of only $16 \%$ of the plants, $51 \%$ of the heads on those plants had one or more larvae. Similarly, heads on $47 \%$ of 9091 Canada thistle ( $C$. arvense) stems sampled had $R$. conicus eggs, and $44 \%$ of the flowers on these stems had $R$. conicus larvae (Rees, 1977). Finally, $60 \%$ of 384 bull thistle (C. vulgare) plants had $R$. conicus eggs, and although only $18 \%$ of the $C$. vulgare plants had live larvae in their flowerheads, $47 \%$ of the heads on those plants were infested.

Unexpectedly, egg and first instar larval mortality on C. nutans were high in Montana, USA, 23.3-82.5\% (Rees, 1977). However, late instar larval mortality was much higher within flowerheads of the Cirsium species than within heads of $C$. nutans in the Gallatin Valley. For example, among the larvae that developed enough to form larval cells, subsequent mortality was $41 \%$ on the native wavyleaf thistle (C. undulatum), versus $31 \%$ on Canada thistle ( $C$. arvense) and $62 \%$ on bull thistle ( $C$. vulgare), compared with less than $3 \%$ on musk thistle (Rees, 1977). Since both Canada and wavyleaf thistles reproduce vegetatively and bull thistle was not a preferred host, Rees (1977) suggested that: 'There is no evidence to date that $R$. conicus will suppress the other thistle species.' Subsequently, Rees (1978) concluded: 'Therefore, $R$. conicus will have little effect on their [Cirsium spp.] populations.'

In summary, based on their interpretation of the evidence available by the early 1980s, Zwölfer and Harris (1984) argued that a combination of four factors would provide strong selection pressure against major utilization of native Cirsium species in North America: (i) strong preference for C. nutans over Cirsium species, especially by the biotype imported from C. nutans; (ii) higher larval mortality on Cirsium species than on Carduus species; (iii) smaller adult size, and so presumably lower fecundity, on Cirsium species than on Carduus species; and (iv) low population densities 
of the North American Cirsium species would not be sufficient to support $R$. conicus population development. Thus, although the data available did not provide strong, unequivocal support for these postulated differences and feeding on native Cirsium species had already been reported, they concluded that despite some concern at the time (1984) it was unlikely that $R$. conicus would have an impact on North American Cirsium species.

\section{Recent studies of Rhinocyllus (1986-1999)}

\section{Variation in phenology}

In North America, recent work supports the hypothesis of latitudinal variation in activity and development of $R$. conicus. For example, in Virginia the activity of overwintered adult weevils was observed to start in mid to late April in Virginia, USA (http://www.nysaes.cornell.edu/ent/biocontrol/ weedfeeders/rhinocyllus_c.html) and in Nebraska on 13 May in 1998 (S.M. Louda, unpublished results). Also, newly developed teneral adults were observed in Colorado, USA, in June and July (http://www.ag.state.co.us/ DPI/publications/muskthistle.html). However, further north in southcentral Alberta, Canada, overwintered adults appeared only in early June and newly emerged adults were seen in August (A.S. McClay, Alberta, 1999, personal communication). Thus, geographical differences in activity pattern can have an environmental component. Furthermore, in Europe, Aeschlimann (1999) confirmed Zwölfer's (1967) observation that the activity period of the $R$. conicus in the more southern Mediterranean climatic region was earlier than that in the more temperate climatic area of Europe. He found that the adults of $R$. conicus in the Mediterranean climate of Montpellier in southern France were active in early spring, and that their progeny started to emerge as adults in the second half of June. Alternatively, the adults of $R$. conicus in the Atlantic climate of Dordogne in south-western France were observed ovipositing later, mainly in early summer, and the new adult progeny started to emerge in mid-July. These results reinforced the suggestion of geographical intraspecific differences in $R$. conicus phenology.

\section{Phenotypic and genetic variation in host use}

In Germany, Klein (1986) studied host selection of $R$. conicus, and he concluded that the sequence in which $R$. conicus would exploit Carduus and Cirsium species within a site was predictable, using plant phenology and flowerhead availability. The earlier flowering species tended to be used first within each site. At Südpfalz, $R$. conicus used Cirsium palustre first, and then $C$. arvense. Near Bad Dürkheim, $R$. conicus used Carduss nutans first and then 
C. acanthoides. In a third study site, c. $20 \mathrm{~km}$ north of Bad Dürkheim, $R$. conicus used $C$. acanthoides, $C$. arvense, C. crispus and then $C$. vulgare (Klein, 1986). Subsequently, Zwölfer (1988) questioned the widespread use of the biotype concept, e.g. by Zwölfer and Preiss (1983). Instead, he proposed that $R$. conicus use of $C$. vulgare in south-western France was more likely due to flowering synchrony rather than to an innate preference for C. vulgare over C. nutans.

In California, Goeden and colleagues pursued their long-term study of variation in $R$. conicus (Goeden et al., 1985; Unruh and Goeden, 1987). Their studies originally suggested a mismatch between host plant and weevil biotype as an explanation for the initial failure of $R$. conicus to establish on S. marianum in California (Hawkes et al., 1972; Goeden, 1978). Allozyme data were consistent with some degree of genetic differentiation of $R$. conicus from milk thistle ( $S$. marianum) from $R$. conicus from musk (C. nutans) and Italian (C. pycnocephalus) thistles. Although only one locus (of five) showed a fixed genetic difference, allelic frequencies at the four other loci differed significantly among weevils from milk, musk and Italian thistles (Unruh and Goeden, 1987). However, Goeden et al. (1985) also found that $R$. conicus from $C$. pycnocephalus did oviposit on $S$. marianum, 6 years after its initial colonization of $C$. pycnocephalus when the flowerheads were nearly saturated with weevil eggs. Interestingly, the $R$. conicus from $S$. marianum began ovipositing on $C$. pycnocephalus quickly, only 1 year after its establishment, and it slowly increased its rate of oviposition on C. pycnocephalus over the next decade. Thus, genetic variation occurred among populations of $R$. conicus. However, the role of that variation in host use by $R$. conicus remained incompletely understood.

In Europe, Klein and colleagues performed a comprehensive allozyme and morphometric analysis of 14 widespread populations of $R$. conicus, collected from France to Israel. They showed that the populations divided into two well-differentiated, concordant groups on both sets of criteria (Klein, 1991; Klein and Seitz, 1994). The groups segregated into a north temperate group and a more southern, Mediterranean climate group, dividing at about the same latitude as the northern distribution border of the cultivated olive tree (Klein and Seitz, 1994). The $R$. conicus adults of the Mediterranean group had a narrower body, a 4 week earlier activity period, and a shorter oviposition period than did those of the temperate group. These traits - smaller size, plus earlier and shorter oviposition period could be adaptations related to use of Silybum species. Klein and Seitz (1994) suggested that the two groups represented subspecies, and they proposed that the Mediterranean subspecies was equivalent to the taxon previously described as Rhinocyllus oblongus Cap. In summary, the evidence now suggests that differences in host use or preference between the two groups (subspecies) of weevils may have a genetic component, whereas differences in host use within each subspecies of $R$. conicus are probably related to temporal availability of flowerheads (Klein, 1986, 1991). 
The temperate $R$. conicus group has been divided further by Briese (1996), into oceanic-climate and continental-climate types. He found that $R$. conicus attacked $C$. pycnocephalus in southern France mainly after $S$. marianum had finished flowering, whereas $R$. conicus from further north were associated instead with Carduus and Cirsium species. Relative use shifted east to west, from primarily Carduus species in the east to primarily Cirsium species in the west. The types also differed in pattern of activity and showed some genetic differentiation, although not as much as between the temperate and Mediterranean groups (Briese, 1996). The oceanic-climate type, which has a long pre-oviposition period after hibernation, was more closely associated with Cirsium species than with Carduus species. The long pre-oviposition feeding period would increase the coincidence of the $R$. conicus oviposition period with later flowering Cirsium species, like C. vulgare, near the Atlantic coast in France. The continental-climate type, which has a short pre-oviposition period after hibernation, was more closely associated with earlier flowering Carduus species than with Cirsium species, although some use of Cirsium species was observed (Zwölfer, 1967; Briese, 1996). Thus, recent research on both continents suggests that host use reflects both a hierarchy of innate host preference and the degree of synchrony between flowering and oviposition periods, with the synchrony influenced by physical conditions.

\section{Non-target feeding on Cirsium species in North America}

Data presented in 1985, plus work in progress at the time, raised again the issue of non-target effects in the biological control of weeds (Andres, 1985; Turner, 1985). Documented reports of feeding by $R$. conicus on native North American Cirsium species were published shortly after by Goeden and Ricker (1986a,b, 1987a,b) and Turner et al. (1987). These studies detailed the development of $R$. conicus within the flowerheads of at least 17 native Cirsium species in California, USA. For two of the native California species (Cirsium californicum Gray, Cirsium proteanum J.T. Howell), Unruh and Goeden (1987) used electrophoretic evidence to suggest that $R$. conicus had transferred on to them from Carduus pycnocephalus, rather than from C. nutans.

These pioneering studies of $R$. conicus on non-target native species are important, since they presage some of the recent findings in the Great Plains. For example, in samples taken in 1983-1985, Turner et al. (1987) found $R$. conicus in $57 \%$ of the native California Cirsium species sampled, representing four of the five sections of Cirsium native to America north of Mexico (Ownbey et al., 1975). Furthermore, they were the first to record that three rare California Cirsium species were readily used by the weevil. In the light of these findings, they stated 'This extension of its host range is not surprising because European Cirsium was known to be within the host 
range of $R$. conicus'. Surprisingly, they also found that the weevils from nontarget Cirsium hosts were significantly larger than those from target Carduus hosts. Finally, Turner et al. (1987) pointed out that $R$. conicus was successful on native Cirsium species, and this contradicted the prevalent idea that native host-specialist insects would competitively exclude introduced biological control insects with a similar trophic niche (e.g. Peschken, 1984).

To date, $R$. conicus has been reared from flowerheads of native Cirsium species in every extensive survey of native Cirsium species in the USA: in California (Goeden and Ricker, 1986a,b, 1987a,b; Turner et al., 1987; Turner and Herr, 1996; Palmisano and Fox, 1997), in Colorado (Louda et al., 1997), in Montana (Rees, 1977, 1991), in Nebraska (Louda et al., 1997; Louda, 1998), as well as South Dakota and Wyoming (Louda et al., 1997). Because of ongoing studies of thistle-insect interactions in prairie grasslands, Louda and colleagues were the first to be able to quantify: (i) the population dynamics of host range expansion by $R$. conicus (Louda, 1998, 2000a); (ii) the consequences of feeding by native floral insect herbivores on the population dynamics of a native thistle, Cirsium canescens Nutt., before the host range expansion of $R$. conicus (Louda et al., 1990, 1992; Louda and Potvin, 1995); (iii) the demographic effects of accelerated seed loss caused by $R$. conicus for $C$. canescens after the expansion (Louda et al., 1997; Louda, 2000a; Louda and Arnett, 2000); and (iv) the indirect effects of $R$. conicus on native inflorescence insects (Louda et al., 1997; Louda and Arnett, 2000; and unpublished data). The evidence from these studies on the ecological effects of $R$. conicus on native Cirsium species in prairies in the north-central USA is summarized below.

\section{Thistle-insect interactions in prairies of the upper Great Plains}

The ongoing studies of the floral herbivores in the population dynamics of native thistles in prairie grasslands were begun in 1976 (Lamp and McCarty, 1979, 1982a,b,c; Lamp, 1980). Four species of native Cirsium have been studied intensely so far: Platte thistle (C. canescens); its close relative, the federally listed threatened Pitcher's thistle (Cirsium pitcheri (Torr.) Torrey and Gray); wavyleaf thistle (C. undulatum (Nutt.) Spreng.); and tall thistle (Cirsium altissimum (L.) Spreng.). All four species are characteristic, short-lived perennial species in prairies. The local distribution of each of these native thistles is patchy (Great Plains Flora Association, 1986; Pavlovic et al., 1992), and none is considered a serious weed (McCarty et al., 1967).

A characteristic set of native insects feeds on or within the developing inflorescences of these thistles. On wavyleaf and Platte thistles in Sandhills prairie, the numerically most native important species damaging flowerheads are: two tephritid flies (Paracantha culta Wiedeman, Orellia occidentale [Snow]); three pyralid moths (Homoeosoma impressale Hulst., Homoeosoma ardaloniphas Goodson and Neunzig, Pyrausta subsequalis plagialis Haim: 
G. Balogh, personal communication); and the adults of a curculionid weevil, Baris subsimilis Casey, whose larvae feed internally on stems and roots (Lamp, 1980; Louda and Potvin, 1995; S.M. Louda, unpublished data; C.W. O'Brien, personal communication). On Pitcher's thistle, the most common insects are the curculionid weevil (B. subsimilis) (C.W. O'Brien, personal communication) and two moths: the artichoke plume moth (Platyptilia carduidactyla; Pterophoridae) and Homoeosoma sp. nr. impressale (Pyralidae) (Louda and McEachern, 1995; and unpublished results).

In the prairie, insect herbivory on native thistles has been quantified for 25 years (Lamp and McCarty, 1979, 1981, 1982c; Louda and McEachern, 1995; Stanforth et al., 1997; Jackson, 1998; Bevill et al., 1999; Louda, 2000a; Louda and Arnett, 2000). These data show that feeding by native insects significantly reduces both flowerhead survival and subsequent seed reproduction by Platte, Pitcher's, tall and wavyleaf thistles. These studies have also been supplemented by experimental evaluation of the role of seed in the population dynamics of platte thistle (Louda et al., 1990, 1992; Louda and Potvin, 1995), wavyleaf thistle in Nebraska sand prairie (Louda, 2000a; S.M. Louda, T. Tesar Huettner and J. Burger, unpublished results) and Pitcher's thistle in dune grasslands around Lake Michigan (Louda and McEachern, 1995; Bevill, 1998; Bevill et al., 1999; and unpublished results). For Platte thistle, insect herbivores were crucial in limiting seed production, seedling establishment, local population density and lifetime fitness (Louda and Potvin, 1995). Seed availability can also limit the seedling establishment of wavyleaf and Pitcher's thistles. Thus, prior to the host range expansion by $R$. conicus, it was known that native inflorescence herbivores limited the seed production and subsequent population density of native thistles in dune grasslands (Louda et al., 1990, 1992; Louda and McEachern, 1995; Louda and Potvin, 1995; Louda, 2000a; Louda and Arnett, 2000; S.M. Louda, unpublished data).

The first indication of the host range expansion by $R$. conicus on to Platte thistle and wavyleaf thistle at two long-term study sites, over $300 \mathrm{~km}$ apart in Nebraska sand prairie, occurred in 1993 (Louda et al., 1997). Population growth of $R$. conicus since 1993 has been nearly exponential (Louda, 1998; 2000a). This host range expansion of $R$. conicus on to the two native Cirsium species occurred more than 20 years after the initial releases into Nebraska (1969-1974) of R. conicus from C. nutans from eastern France and north-central Italy. It is important to note that no Carduus species occur at the study sites in the Sandhills of Nebraska. The population growth of $R$. conicus in the Sandhills prairie nature preserves is consistent with the other evidence available on $R$. conicus use of the flowerheads of native thistles in the upper Great Plains (Louda et al., 1997). Initial utilization of the native Cirsium species as hosts has been greatest on the early flowering species, and lowest on the high elevation $(4150 \mathrm{~m})$ species. Activity by $R$. conicus in Nebraska sand prairie is relatively early. Mating and oviposition by overwintered adults have been observed from mid-May to 
mid-June, with the new generations emerging from mid-July to mid-August (Louda, 1998).

The initial increase of $R$. conicus in the Sandhills of Nebraska has been most significant for seed production and population demography of the earlier flowering species, Platte thistle (C. canescens) (Louda, 2000b). Louda (1998) hypothesized that synchrony of flowering with the period of $R$. conicus oviposition activity helped to explain this difference in initial susceptibility to $R$. conicus between the co-occurring native species, $C$. canescens and $C$. undulatum. The average number of viable seeds produced by flowerheads of Platte thistle infested with weevils in 1996 was $14.1 \%$ of that produced by similar heads with no insects or only native insects (Louda et al., 1997, 1998). The weevil increased the number of seeds lost to all insects, both per head and per plant (Louda, 2000a). Since the recruitment, density and fitness of Platte thistle were previously shown to be proportional to the number of viable seeds (Louda and Potvin, 1995), the added fivefold reduction in seed imposed by $R$. conicus leads to the prediction of a severe, potentially fivefold, reduction in plant population density of this already sparse native species. Data from demography plots (1990-1999) are consistent with this prediction (Louda, 2000a; Louda and Arnett, 2000). Finally, the striking, well-documented parallels between Platte thistle and its rare congener, Pitcher's thistle (C. pitcheri [Torr.] Torrey and Gray) (Louda, 1994; McEachern et al., 1994; Louda and McEachern, 1995; Bevill et al., 1999), suggest that the same thing could happen to Pitcher's thistle if $R$. conicus were to become established in the dune ecosystem around the Great Lakes (Louda et al., 1997, 1998).

Additionally, the experimental evidence now provides support for the hypothesis of indirect ecological effects of $R$. conicus on the native inflorescence insects. These insects exploit flowerheads of the same stage and size as those used by $R$. conicus (Mellini, 1951; Harris and Zwölfer, 1971; Lamp and McCarty, 1982a,c; Zwölfer and Preiss, 1983; Zwölfer and Harris, 1984). A dramatic drop in the numbers of the early tephritid, Paracantha culta, in Platte thistle (C. canescens) flowerheads was correlated with the sharp increase in the numbers of $R$. conicus from 1994 to 1996 (Louda, $1998,2000 \mathrm{a})$. In a recent experimental test, the number of $P$. culta reared per head increased dramatically when the $R$. conicus eggs were removed by hand, compared with both control flowerheads and flowerheads on which $R$. conicus eggs were experimentally augmented (Louda, 2000a; Louda and Arnett, 2000; and unpublished data).

In summary, post-release ecological studies of the use of native thistles by $R$. conicus show five main patterns: (i) occurrence is geographically widespread (Goeden and Ricker, 1986a,b; Turner et al., 1987; Turner and Herr, 1996; Louda et al., 1997; Palmisano and Fox, 1997); (ii) levels of use of native thistles in the central USA are high and increasing (Louda et al., 1997, 1998); (iii) exponential population growth on native thistles in Nebraska showed a long (i.e. more than 20 years) lag after introduction 
(Louda, 1998); (iv) both direct and indirect effects occurred; and (v) the greatest obvious impact so far has been on a species that is monocarpic, phenologically synchronized with $R$. conicus, characterized by a short flowering period, and limited in population density by seed availability. Louda and colleagues (Louda et al., 1997, 1998; Louda, 2000a,b; Louda and Arnett, 2000) have argued that, although the occurrence of some feeding by $R$. conicus on North American Cirsium was considered likely (Zwölfer and Harris, 1984), neither the amount of that feeding nor the size of the ecological effects associated with this feeding were predictable from the data taken in pre- and early post-release studies.

\section{Altered ecological interactions in the new environment?}

One prerequisite for success in the biological control of weeds, and that may lead to unexpected pressure on non-target plant hosts in a new environment, is that the herbivore population can reach high enough densities to reduce target host plant performance and density (Gassmann, 1996). The potential for such population growth is set by a species' innate demographic characteristics. These traits, in turn, are constrained by various ecological factors, such as interactions with natural enemies and resource competitors, as well as by host plant quality, climatic variability and habitat conditions. One possible explanation for the large non-target effects of $R$. conicus in North America is that the weevil was released from ecological constraints, such as imposed by its specialized natural enemies (Zwölfer and Harris, 1984) and by its adapted, inflorescence-feeding competitors (Zwölfer, 1978, 1988). In fact, based on the oviposition patterns of the weevil in Europe, Zwölfer (1971) thought that the selection of $R$. conicus for release in North America was 'fortunate', since high egg potential and a tendency to disperse its eggs should allow $R$. conicus to exert strong pressure on its host plant, after the weevil was released from limitation by its co-evolved competitors and parasitoids. Yet, these traits also contribute to high population growth rates and high densities, and so could increase the chance of both a spillover on to nearby native Cirsium species and dispersal movement into areas without its targeted (Carduus species) hosts. Although a greater diversity of parasitoids and predators on $R$. conicus is reported in North America than in Europe, the rates of parasitism were much lower in North America than in Europe (Zwölfer and Harris, 1984). Lower parasitism rates could allow the population build-up observed for $R$. conicus in North America, on both Carduus species in areas of deliberate introduction (e.g. Rees, 1977, 1982) and on Cirsium species in areas subsequently invaded (Louda, 1998). The role of these interactions in population growth and size of $R$. conicus merit further study.

In addition, interspecific competition with other co-evolved phytophagous insects, such as Urophora solstitialis and Larinus sturnus, within 
C. nutans heads in Europe is a major cause of $R$. conicus mortality, and it probably contributes to limiting population growth there (Zwölfer, 1979; Zwölfer and Harris, 1984). Although native insects utilize the inflorescences of North American Cirsium species, interspecific competition could be lower in North America. The Nearctic inflorescence-feeding guild is simpler (Zwölfer, 1988), and in the upper Great Plains it lacks any native cleonine weevils (O'Brien and Wibmer, 1982). A decrease in guild competitive intensity could allow high population growth rates of $R$. conicus and lead to a spillover effect on to native Cirsium species. However, no data are yet available to document the occurrence of such a spillover effect.

Furthermore, there is conflicting evidence on the outcome of competition of $R$. conicus with tephritid flies. On C. nutans in Australia, Woodburn (1996) recently found $R$. conicus is unexpectedly out-competing $U$. solstitialis, the more effective biological control agent, even though $U$. solstitialis was thought to out-compete $R$. conicus in Europe (Zwölfer, 1979). On Platte thistle in Nebraska, $R$. conicus is outcompeting the native tephritid, $P$. culta (Louda and Arnett, 2000; and unpublished results). Unfortunately, no direct tests have been done on the interaction strengths and relative effects of competitors and predators on $R$. conicus population dynamics in either Europe or North America. $R$. conicus actually has natural enemies and significant potential competitors in the native inflorescence insects in North America as well as in Europe. Thus, these interactions need more evaluation, as does the hypothesis of more rapid population growth of $R$. conicus, with potential spillover on to Cirsium species, in North America.

One strategy for persistence in the face of a strong competitor is to 'spread the risk' by dispersing eggs widely. In Europe, at Mulhouse, France, $98.2 \%$ of the flowerheads of $C$. nutans were attacked by $R$. conicus in 1971, and the variance-to-mean ratio of eggs per $C$. nutans head was 0.70 (Zwölfer, 1971, 1979). As a result of predation and interspecific competition, the variance-to-mean ratio of the late larval/pupal distribution was higher (2.1-3.9) than that of eggs (Zwölfer, 1979). There was a highly significant negative correlation between the developmental success of R. conicus and the presence of Urophora and Larinus larvae (Zwölfer, 1979). Interestingly, the variance-to-mean ratio for its competitors suggested that they were more clumped; the variance-to-mean ratios were 9.6 for $U$. solstitialis ( $40.5 \%$ of the heads attacked), and 1.6 for L. sturnus (Zwölfer, $1971,1979)$. In the United States, weevil aggregation was stronger than in Europe. In Montana, following the release of 2940 adult weevils at five sites between 1969 and 1973, the 'percentage of plants with eggs on flowers' increased from $88 \%$ in 1975 to $98 \%$ and $99 \%$ in 1976 and 1977 , respectively (Rees, 1978). The variance-to-mean ratio of eggs per primary (terminal) flowerhead increased from 2.4 in 1975 to 37.9 in 1976, and 61.8 in 1977 (Rees, 1978). After egg and early larval instar mortality, the variance-tomean ratio of third instar larvae in primary heads became even greater, going from 4.5 in 1975 to 5.1-5.8 in 1976 and 1997 (Rees, 1978), perhaps as 
a result of intraspecific competition. In Nebraska, Louda (1998) also reported strongly aggregated use of native thistles ( $C$. canescens, $C$. undulatum) by adults of $R$. conicus. For example, between 1994 and 1996 , the variance-to-mean ratio for adult $R$. conicus on Platte thistle (C. canescens) in May averaged 8.4 at Arapaho Prairie and 11.9 at the Niobrara Valley Preserve. Interestingly, the average variance-to-mean ratio for late larval/pupal number of $R$. conicus per Platte thistle plant, in the same period, increased substantially over that of the adult aggregation pattern, to 17.6 at Arapaho and 13.7 at Niobrara (S.M. Louda, unpublished data). In any case, although the data available for Europe and North America are not strictly comparable, they suggest that the distribution of the eggs and larvae of $R$. conicus on $C$. nutans tend to be more evenly dispersed in the indigenous region. Oviposition behaviour of $R$. conicus, which determines egg load distribution in Europe and North America, is also in need of further research to provide a better basis for predicting effectiveness.

\section{Discussion}

Our aim was to summarize the information available to provide a basis from which to address the general question of whether what was known, pre-release and early post-release, was sufficient to predict both the occurrence and the magnitude of impact by $R$. conicus on native thistles and their adapted floral insects. At least two main issues are confounded within the discussions over the risks associated with the deliberate introduction of exotic species for the control of exotic pest species. One issue is scientific: what evidence is required to evaluate the risks associated with various control methods, including those specific to classical biological control. The other issue is political, and can involve more rhetoric and hyperbole than fact. The evidence reviewed here can only be used to address the former issue. A review of such evidence in specific case histories is one way to learn from past mistakes in order to improve future efforts in biological control. Presumably such evidence will eventually be useful in a public context to resolve the political issue (Miller and Aplet, 1993).

Our first conclusion is that, in retrospect, the implications of the pre-release and early post-release data were that $R$. conicus would be likely to feed and develop upon some North American Cirsium species. The evidence suggesting the potential for problems appears to have been undervalued, reflecting both major reliance on field records to define the relative ranking among accepted hosts and the widespread acceptance of the idea of innate host preferences (biotypes) determining host-plant specificity. Our second conclusion, however, is that the studies needed to quantify the likely direct ecological consequences of that potential feeding on native species were not done, nor were studies done to examine the potential indirect effects of such feeding. Thus, in retrospect, more tests were 
required to complete the assessment of the ecological implications of the documented diet breadth. It is clear, however, that economic, not environmental, risks were the main focus of the scientific assessment of $R$. conicus for the biological control of thistles. The rationale for our conclusions reflects the information presented above and the following assessment of it.

\section{Host specificity: feeding acceptance, oviposition and larval performance}

The most consistent criteria used for the evaluation of potential non-target feeding are measures of insect host specificity or diet breadth (McEvoy, 1996). Generally, these measures include: (i) feeding acceptance when starved; (ii) feeding preference when given a choice; (iii) oviposition (under choice and no-choice conditions); and (iv) subsequent larval performance on a range of related and unrelated potential host plants. Feeding tests of $R$. conicus on leaf material, both starvation (= no-choice) and preference (= choice) evaluations, were done early in the programme. In the starvation tests of $R$. conicus from $C$. nutans, the form introduced into most areas of North America including Nebraska, the intensity of feeding on most Cirsium species as well as weevil survival on C. undulatum were lower than that on C. nutans. However, it was clear that some Cirsium species were accepted, including the one North American native species that was tested, C. undulatum (Zwölfer, 1964, 1967; Zwölfer and Harris, 1984). In the feeding preference tests of $R$. conicus from $C$. nutans carried out by Zwölfer (1964, 1967) and summarized by Zwölfer and Harris (1984), no consistent preference was detected for Carduus species over Cirsium species (Zwölfer, 1964). Despite this, the patterns in the field, plus the conviction that $R$. conicus was divided into host-specific races, led to the interpretation that feeding on native Cirsium would be slight (Zwölfer and Harris, 1984).

Oviposition and subsequent larval performance were also at least partially evaluated. First, field data on host use suggested a strong association with the targeted weeds. Second, egg deposition while feeding on leaves in no-choice tests was recorded, but the meaning of such data is ambiguous. Third, the no-choice oviposition tests done in field cages with four European species (two Carduus spp., two Cirsium spp.) showed that both Carduus and Cirsium species would support complete larval development (Zwölfer, 1967; Zwölfer and Harris, 1984). The field associations received more emphasis than did the garden oviposition tests. However, although the early field data suggested that $R$. conicus generally had a strong preference for $C$. nutans over Cirsium species, the realized pattern of use in the field was also influenced by environmental conditions and biotic interactions as well as innate preferences. Further, the laboratory tests did not substantiate a clear preference for Carduus over Cirsium per se, but suggested a preference among species within each genus. Today, such results would be viewed as evidence that further, larger-scale tests 
were warranted to quantify the factors determining the patterns and the variation in feeding impact and insect performance (relative adult survival, female oviposition, larval survival). Further choice and no-choice oviposition tests, including native North American species, to quantify relative egg loads among acceptable species, would have helped to calibrate the relative risk to Cirsium vs. Carduus species. Recently, Arnett and Louda (unpublished data) found that $R$. conicus from Nebraska still exhibited feeding and oviposition preferences for $C$. nutans over the native C. canescens, but also showed significant levels of acceptance of $C$. canescens even in the presence of $C$. nutans. Added no-choice oviposition and larval development tests with synchronously flowering native North American Cirsium species, such as $C$. canescens (Platte thistle), would also have improved quantification of the direct ecological risk to natives at low densities or in the absence of the targeted host plant. Such tests should be done as background for contemporary biological control decisions.

Given Zwölfer's (1967) early suggestion that flowering phenology probably influenced host use by $R$. conicus in the field in temperate Europe, we wonder about the real meaning of the evidence on feeding and oviposition preference. To what extent could the evidence on preference reflect environmental differences - the result of experience, physical conditions or ecological context - rather than innate, heritable differences? The data in the unpublished early reports (e.g. Zwölfer, 1964, 1967) suggested that the innate preference of $R$. conicus is likely to be only a partial predictor of host use in the field. Based on his field observations, Zwölfer (1967) suggested that a possible explanation for the variation in the use of $C$. vulgare in Italy and France 'may be found in the different phenology of the weevil populations ... The upper Rhine Valley populations of $R$. conicus start their activity very early and are better synchronized with $C$. nutans than with $C$. vulgare, whilst the contrary may be the case with the Apennines populations.' Genetic variation exists among populations of $R$. conicus in Europe and those introduced into California (Goeden, 1978; Goeden et al., 1985; Unruh and Goeden, 1987; Klein, 1991; Klein and Seitz, 1994; Briese, 1996). However, genetically determined host plant specialization is not sufficient to explain either the patterns of variation in host choice or geographical variation in that choice within the indigenous region.

Even though an ecological factor (flowering phenology) was initially suspected to be a critical parameter for predicting host use in the field, no further studies of ecological factors were performed. Instead, the reliance on patterns in the field survey and on evidence of some genetic variation, plus the inference that such variation contributed significantly to host specificity, were widely accepted (e.g. Zwölfer and Preiss, 1983; Zwölfer and Harris, 1984). In retrospect, this was unfortunate. The wide geographical range, and evidence of the associated broad ecological tolerance of $R$. conicus across Europe, as well as the feeding breadth within the Subtribe Carduinae, which contained native North American species, should have 
stimulated further studies of the ecological parameters involved in the host choice, reproductive success and population growth of $R$. conicus.

\section{Host specificity: larval survival and performance}

The second part of most evaluations of the potential risk of non-target use involves evaluating insect host specificity by larval performance on the range of accepted potential host plants. Larval performance is generally defined by survival, development time and subsequent adult size. Lack of complete development in a well-designed test is reasonable evidence that immediate ecological effects are unlikely, although it does not preclude strong selection for adaptation under the right circumstances over the longer run (Secord and Kareiva, 1996). Slower rates of larval development have been interpreted as evidence of low impact potential (Zwölfer and Harris, 1984). However, this case history demonstrates that such evidence can underestimate the eventual use and ecological impact of the biological control agent on a less preferred non-target species (Louda et al., 1997; Louda, 1998, 2000a; Louda and Arnett, 2000). With the pre-release tests in Europe and early post-release studies of $R$. conicus, for example, Zwölfer and Harris (1984) inferred that larval survival of $R$. conicus was higher, development was faster, and subsequent adults were larger on $C$. nutans than on Cirsium species. Thus, they concluded that 'a combination of the preference of the $C$. nutans strain of the weevil for its own host species, a high [larval] mortality and presumably low fecundity resulting from small size when reared on other thistles implies a strong selection pressure against their [Cirsium spp.] utilization.' They also argued that 'to overcome the negative selection pressures of adult oviposition preferences and high larval mortality, the thistle involved should be abundant. Thus it is unlikely that the normally scattered native thistles will be adopted as a prime host.'

Unfortunately, this has not turned out to be the case. Feeding and oviposition preferences were not relevant when Cirsium species occurred without Carduus species (Louda, 1998; Arnett and Louda, unpublished data). Development of larvae into adults on Flodman's thistle ( $C$. flodmanii) in Canada (Maw, cited in Zwölfer and Harris, 1984), and on Platte (C. canescens) and wavyleaf (C. undulatum) thistles in Nebraska (Louda, 1998; Arnett and Louda, unpublished data) was high, though not as high as on Carduus species. In fact, in Nebraska, we know that larval survival and development were sufficient to lead to explosive population growth (Louda, 1998). So, the population growth and impact of $R$. conicus on Platte and wavyleaf thistles, specifically, has occurred in spite of lower larval survival and development on these species. This suggests that we should 'believe our data' (Louda, 2000a) and pursue contradictions and conflicting data if they emerge in early tests. 
In summary, the preference and performance data from pre-release studies and early post-release studies suggested that some Cirsium species were acceptable host plants, and that development could be completed on them. Since differences in rates of acceptance and development were considered significant, and the economic imperative was primary, none of the further testing suggested by the data was undertaken. Contemporary concerns over environmental risk should make such tests standard now.

\section{Prediction of quantitative ecological effects}

Given that the preference and performance data actually did show that $R$. conicus would feed and develop on some Cirsium species in Europe, and so would be likely to use some Cirsium species in North America, were the observed population build-up and numerical impact of the weevil on the non-target North American thistles predictable? Moreover, were the indirect negative impacts on the associated native floral insects predictable? In the context of the usual contemporary testing protocols, to what extent did the standard preference and performance tests predict the ecological effects of $R$. conicus now documented? Are preference and performance tests sufficient to predict what 'intermittent feeding' under test conditions portends under new environmental conditions? The review of the data suggests that preference and performance, as evaluated in this case, were necessary but not quite sufficient to predict the numerical effects of $R$. conicus on less preferred host species under field conditions. Three types of evidence support this interpretation.

Firstly, actual testing of native North American species was clearly not a high priority of the biological control programmes before 1985, with the Euphorbia esula L. programme being a notable exception in North America (Pemberton, 1985a). For $R$. conicus, none of the pre-release choice tests included native North American species (Zwölfer, 1967; Zwölfer and Harris, 1984). Only two of the early post-release studies looked for development of $R$. conicus on native North American Cirsium species; one unpublished study in Canada on C. flodmanii (Maw, cited in Zwölfer and Harris, 1984) and one in Montana on C. undulatum (Rees, 1978). These results for native species contrast with the much more extensive evaluation of economic plant species (Zwölfer, 1964, 1967, 1969; Zwölfer and Harris, 1984).

Secondly, without evaluating the mechanisms leading to relative egg loads under field conditions in Europe, the quantitative use of various Cirsium species in North America could not be predicted. Observed patterns of utilization are influenced by environmental differences, and laboratory patterns of preference may or may not predict the relative amount of use among acceptable species under variable field conditions. In addition, no studies were carried out to quantify the consequences of 
feeding on the less preferred populations of potential host plant species within the main regions of study, either in Europe or in North America. Such tests are required to provide some insights into the potential quantitative impact of feeding, when the preferred host is unavailable or when ecological conditions in the field shift the spectrum of host resources available. Such field data, in addition to the adult preference tests and subsequent larval performance tests, would probably have identified the potential magnitude of the non-target feeding impact of $R$. conicus on early flowering native North American Cirsium species that occur within the altitudinal range of the weevil.

Thirdly, comparative studies of the reproductive biology and life tables of Rhinocyllus 'biotypes' on non-target key species could have been used to test the hypothesis of population build-up by each 'biotype' under new environmental conditions. Comparative studies in Europe and North America of the flowerhead guild of thistle species, with and without Rhinocyllus, could have helped in understanding the role of horizontal effects, such as competition interference and cannibalism, on Rhinocyllus dynamics as well as the indirect impacts on other insects.

Thus, further studies of variable host plant use in Europe should have been used to determine the relative risk to Cirsium species under different environmental conditions, and to evaluate Zwölfer's (1967) early inference that ecological context could be critical. These studies could have quantified egg loads and larval success rates on less preferred plant host species, such as some Cirsium species, both near to and removed from the vicinity of a more preferred Carduus species of host plants. Similarly, these parameters could also have been tested under different physical conditions, such as those that affect phenology. Post-release comparative and experimental studies of feeding and oviposition on potentially acceptable North American Cirsium species were, and continue to be, merited for potentially vulnerable and rare species and for those whose flowering phenology coincides with the oviposition period of $R$. conicus. The type of studies needed could be designed on the model of the recent field assessment of the quantitative role of floral herbivores in the population density and dynamics of C. nutans in France (Sheppard et al., 1990, 1994) or in New Zealand (Shea and Kelly, 1998), if they were extended to evaluate impacts on other acceptable species besides the one targeted for control.

\section{Conclusions}

Our review of the evidence on $R$. conicus and its relevance for resolving the controversy over the data available was required to assess the risk of deliberate introductions for the biological control of weeds, such as true thistles, and it leads to three conclusions. 
First, in retrospect, the pre-release plus the early post-release data did suggest that $R$. conicus would be likely to feed, and could develop, on multiple Cirsium species, including important clues that North American species would be among these species. However, several factors influencing the programme at the time led the investigators to discount this evidence. These factors were: (i) a widespread acceptance of the host race paradigm; (ii) a focus on preventing damage to economic plants, which entailed selecting test plants for the screening tests which were almost exclusively cultivated plants; and (iii) a strong desire to move quickly to eliminate the weed problem. These factors contributed to a de-emphasis on the data that showed significant feeding, oviposition and development on some European and a couple of North American Cirsium species. A strong emphasis was placed, instead, on why the evidence was not sufficient to predict a major effect by $R$. conicus on native plant species. This latter emphasis precluded further studies, to examine conflicting data and to determine the ecological factors influencing host selection in the field.

Second, again in retrospect, the studies needed to quantify the likely magnitude of feeding and development by $R$. conicus on Cirsium species, and thus the ecological consequences of that feeding, were not done in this case, nor in any other up to that time as far as we are aware. Thus, a clear prediction of the intensity of direct effects, and of the type and magnitude of indirect ecological effects resulting from the feeding and potential development, was not possible. However, the early data did provide reasons to hypothesize that ecological effects might occur if $R$. conicus did include North American Cirsium species in its list of acceptable, phenologically exploitable host plants. For example, starvation feeding tests showed 'regular and spontaneous feeding' by $R$. conicus on at least two European Cirsium spp. (C. arvense, C. vulgare), and preference feeding tests showed higher acceptance of European Cirsium acaule than of Carduus nutans. Furthermore, larval development was also completed on European Cirsium arvense and C. palustre.

Third, the findings imply the potential for a direct, negative effect by $R$. conicus on fitness and seed production of Cirsium species when exploited. Interactions with other insects in the floral herbivore guild were noted, implying the potential for indirect interactions with insects in the North American inflorescence guild. However, these clues in the observations and data from pre-release and early post-release studies were not pursued. Some of the information needed could have been developed through quantitative field studies of relative egg loads on alternative hosts, under a range of environmental conditions within the geographical range of $R$. conicus in Europe. Such data would quantify the potential variation in magnitude of use of less preferred, but acceptable, host plant species. Thus, we conclude that more information could have been acquired to assess the ecological consequences and potential control effectiveness, and these data are now required under contemporary conditions. 
In summary, we conclude that there were enough data suggesting that Cirsium species were acceptable host species to have aroused more suspicion over the potential consequences of introducing and redistributing $R$. conicus in North America without further testing. However, accurate prediction of the observed quantitative ecological effects would have required more field and laboratory experiments. Contemporary concerns now mandate such additional, pre-release testing.

\section{Acknowledgements}

We are grateful to R.W. Pemberton and U. Schaffner for their comments on an earlier draft of the manuscript. The field data collections in Great Plains prairies were assisted by many competent students and colleagues, to whom S.M. Louda is deeply grateful. C.W. O'Brien identified curculionids and G. Balogh identified the lepidopterans in the North American thistle flowerheads. Support for research on North American thistles has been provided to S.M. Louda by The National Science Foundation (DEB9221065, DEB96-16210), the Ordway and Johnson Stewardship Fund of The Nature Conservancy and four grants (1985-1992) from the University of Nebraska Research Council.

\section{References}

Aeschlimann, J.-P. (1999) Specificity and bionomics of south-western Palaearctic biotypes of Rhinocyllus conicus Frölich (Col., Curculionidae), a biological control agent of Palaearctic thistles (Asteraceae) accidentally introduced to Australia. Mitteilungen der Schweizerischen Entomologischen Gesellschaft 72, 11-22.

Andres, L.A. (1985) Interactions of Chrysolina quadrigemina and Hypericum spp. in California. In: Delfosse, E.S. (ed.) Proceedings of the 6th International Symposium on Biological Control of Weeds. 19-25 August 1984, Agriculture Canada, Vancouver, pp. 235-239.

Bevill, R.L. (1998) The study and management of rare plant species with special attention to the threatened Pitcher's thistle and insect herbivory. MSc. thesis, University of Nebraska, Lincoln.

Bevill, R.L., Louda, S.M. and Stanforth, L.M. (1999) Protection from natural enemies in managing rare plant species. Conservation Biology 13, 1323-1331.

Boldt, P.E. (1978) Foreign exploration for the biological control of Carduus spp. In: Frick, K.E. (ed.) Biological Control of Thistles in the Genus Carduus in the United States. Progress Report, USDA-SEA, Stoneville, Mississippi, pp. 11-17.

Boldt, P.E., and DeLoach, C.J. (1985) Evaluating Rhinocyllus conicus (Coleoptera: Curculionidae) on Silybum marianum (Compositae) in Texas. In: Delfosse, E.S. (ed.) Proceedings of the 6th International Symposium on Biological Control of Weeds 19-25 August 1984, Agriculture Canada, Vancouver, pp. 235-239.

Boldt, P.E. and Jackman, J.A. (1993) Establishment of Rhinocyllus conicus Frölich on Carduus macrocephalus in Texas. The Southwestern Entomologist 18, 173-181. 
Briese, D.T. (1996) Phylogeny: can it help us to understand host choice by biological weed control agent? In: Moran, V.C. and Hoffmann, J.H. (eds), Proceedings of the 9th International Symposium on Biological Control of Weeds, 19-26 January 1996. University of Cape Town, Stellenbosch, South Africa, pp. 63-70.

Buntin, G.D., Hudson, R.D. and Murphy, T.R. (1993) Establishment of Rhinocyllus conicus (Coleoptera: Curculionidae) in Georgia for control of musk thistle. Journal of Entomological Science 28, 213-217.

Desrochers, A.M., Bain, J.J. and Warwick, S.I. (1988) A biosystematic study of the Carduus nutans complex in Canada. Canadian Journal of Botany 66, 1621-1631.

Dowd, P.F. and Kok, L.T. (1981a) Impact of larval crowding on survival of Rhinocyllus conicus (Coleoptera: Curculionidae). Environmental Entomology 10, 472-473.

Dowd, P.F. and Kok, L.T. (1981b) Predators of Rhinocyllus conicus (Coleoptera: Curculionidae) in Virginia. Environmental Entomology 10, 136-138.

Dowd, P.F. and Kok, L.T. (1982) Parasitism of Rhinocyllus conicus in Virginia. Environmental Entomology 11, 71-77.

Dowd, P.F. and Kok, L.T. (1983) Influence of soil conditions on Carduus thistles and development of the thistle head weevil, Rhinocyllus conicus (Coleoptera: Curculionidae). Environmental Entomology 12, 439-441.

Dunn, P.H. (1976) Distribution of Carduus nutans, C. acanthoides, C. pycnocephalus, and C. crispus, in the United States. Weed Science 24, 518-524.

Dunn, P.H. (1978) History of the biological control of musk thistle in North America and studies with the flea beetle Psylloides chalcomera. In: Frick, K.E. (ed.) Biological Control of Thistles in the Genus Carduus in the United States. Progress Report, USDA-SEA, Stoneville, Mississippi, pp. 1-6.

Frank, J.H. (1998) How risky is biological control? Comment. Ecology 79, 1829-1834.

Gassmann, A. (1996) Classical biological control of weeds with insects: a case for emphasizing agent demography. In: Moran, V.C. and Hoffmann, J.H. (eds) Proceedings of the 9th International Symposium on Biological Control of Weeds, 19-26 January 1996. University of Cape Town, Stellenbosch, South Africa, pp. 171-175.

Goeden, R.D. (1978) Initial analysis of Rhinocyllus conicus Frölich (Col.: Curculionidae) as an introduced natural enemy of milk thistle (Silybum marianum (L.) Gaertner) and Italian thistle (Carduus pycnocephalus L.) in southern California. In: Frick, K.E. (ed.) Biological Control of Thistles in the Genus Carduus in the United States, Progress Report, USDA-SEA, Stoneville, Mississippi, pp. 39-50.

Goeden, R.D. and Ricker, D.W. (1977) Establishment of Rhinocyllus conicus on milk thistle in southern California. Weed Science 25, 288-292.

Goeden, R.D. and Ricker, D.W. (1978) Establishment of Rhinocyllus conicus on Italian thistle in southern California. Environmental Entomology 7, 787-789.

Goeden, R.D. and Ricker, D.W. (1985) Seasonal asynchrony of Italian thistle, Carduus pycnocephalus, and the weevil, Rhinocyllus conicus (Coleoptera: Curculionidae), introduced for biological control in southern California. Environmental Entomology 14, 433-436.

Goeden, R.D. and Ricker, D.W. (1986a) Phytophagous insect faunas of the two most common native Cirsium thistles, C. californicum and C. proteanum, in southern California. Annals of the Entomological Society of America 79, 953-962. 
Goeden, R.D. and Ricker, D.W. (1986b) Phytophagous insect faunas of two introduced Cirsium thistles, $C$. ochrocentrum and $C$. vulgare, in southern California. Annals of the Entomological Society of America 79, 945-952.

Goeden, R.D. and Ricker, D.W. (1987a) Phytophagous insect faunas of native Cirsium thistles, C. mohavense, C. neomexicanum, and C. nidulum, in the Mojave Desert of southern California. Annals of the Entomological Society of America 80, 161-175.

Goeden, R.D. and Ricker, D.W. (1987b) Phytophagous insect faunas of the native thistles, Cirsium brevistylum, Cirsium congdonii, Cirsium occidentale, and Cirsium. tioganum in southern California. Annals of the Entomological Society of America 80, $152-160$.

Goeden, R.D., Ricker, D.W. and Hawkins, B.A. (1985) Ethological and genetic differences among three biotypes of Rhinocyllus conicus (Coleoptera: Curculionidae) introduced into North America for the biological control of Asteraceous thistles. In: Delfosse, E.S. (ed.) Proceedings of the 6th International Symposium on Biological Control of Weeds. 19-25 August 1984, Agricuiture Canada, Vancouver, pp. 181-189.

Great Plains Flora Association (1986) Flora of the Great Plains. University Press of Kansas, Lawrence.

Harris, P. (1984) Carduus nutans L., nodding thistle and C. acanthoides L., plumeless thistle (Compositae). In: Biological Control against Insects and Weeds in Canada 1969-1980. CIBC, Technical Communication No.4, pp. 115-126.

Harris, P. and Zwölfer, H. (1971) Carduus acanthoides L., welted thistle, and C. nutans L., nodding thistle (Compositae). In: Biological Control Programmes against Insects and Weeds in Canada 1959-1968. CIBC, Technical Communication No. 4, pp. 76-79.

Hawkes, R.B., Andres, L.A. and Dunn, P.H. (1972) Seed weevil released to control milk thistle. California Agriculture 26, 14.

Hodgson, J.M. and Rees, N.E. (1976) Rhinocyllus conicus for biocontrol of musk thistle. Weed Science 24, 59-62.

Hoffmann, A. (1954) Faune de France - Coléoptères Curculionides, Vol. 59, Editions Paul Lechevalier, pp. 521-547.

Howarth, F.G. (1983) Classical biocontrol: panacea or Pandora's box? Proceedings of the Hawaiian Entomological Society 24, 239-244.

Howarth, F.G. (1991) Environmental impacts of classical biological control. Annual Review of Entomology 36, 485-509.

Jackson, K.S. (1998) Ecological factors affecting reproductive success of tall thistle (Cirsium altissimum): insect herbivory, nutrient availability, and competition. MSc. thesis, University of Nebraska, Lincoln.

Jessep, C.T. (1981) Progress report on biological control of nodding thistle (Carduus nutans) in New Zealand. In: Delfosse, E.S (ed.) Proceeding of the 5 th International Symposium on Biological Control of Weeds. 22-29 July 1980. CSIRO, Brisbane, pp. 635-637.

Julien, M.H. and Griffiths, M.W. (eds) (1998) Biological Control of Weeds. A World Catalogue of Agents and their Target Weeds. 4th edn, CAB International, Wallingford, UK.

Klein, M. (1986) Anpassung von Rhinocyllus conicus Fröl. (Col., Curculionidae) an allochrone Wirtspflanzensituationen. Verhandlung der Deutschen Zoologischen Gesellschaft. Gustav Fischer Verlag, Stuttgart, pp. 175-176. 
Klein, M. (1991) Populationsbiologische Untersuchungen an Rhinocyllus conicus Fröl. (Col., Curculionidae). PhD thesis, University of Mainz, WissenschaftsVerlag Maraun, Frankfurt/Main.

Klein, M. and Seitz, A. (1994) Geographic differentiation between populations of Rhinocyllus conicus Frölich (Coleoptera: Curculionidae): concordance of allozyme and morphometric analysis. Zoological Journal of the Linnean Society 110 , 181-191.

Kok, L.T. (1974) Efficacy of spring releases in colonization of Rhinocyllus conicus for the biocontrol of thistles. Environmental Entomology 3, 429-430.

Kok, L.T. and Surles, W.W. (1975) Successful biocontrol of Musk thistle by an introduced weevil, Rhinocyllus conicus. Environmental Entomology 4, $1025-1027$.

Laing, J.E. and Heels, P.R. (1978) Establishment of an introduced weevil Rhinocyllus conicus (Coleoptera: Curculionidae) for the biological control of nodding thistle (Compositae) in southern Ontario. Proceedings of the Entomological Society of Ontario 109, 3-8.

Lamp, W.O. (1980) Predispersal seed predation of the Platte thistle and its effect on seed production. PhD thesis, University of Nebraska, Lincoln.

Lamp, W.O. and McCarty, M.K. (1979) A preliminary study of seed predators of Platte thistle. Transactions of the Nebraska Academy of Sciences 7, 71-74.

Lamp, W.O. and McCarty, M.K. (1981) Biology and ecology of Platte thistle (Cirsium canescens). Weed Science 29, 686-692.

Lamp, W.O. and McCarty, M.K. (1982a) Biology of predispersal seed predators of the Platte thistle (Cirsium canescens). Journal of the Kansas Entomological Society 55 , $305-316$.

Lamp, W.O. and McCarty, M.K. (1982b) Observations of Conythucha distincta (Hemiptera: Tingidae) on Platte thistle in Nebraska. Journal of the Kansas Entomological Society 55, 34-36.

Lamp, W.O. and McCarty, M.K. (1982c) Predispersal seed predation of a native thistle, Cirsium canescens. Environmental Entomology 11, 847-851.

Louda, S.M. (1994) Experimental evidence for insect impact on populations of short-lived, perennial plants, and its application in restoration ecology. In: Bowles, M.L. and Whelan, C.J. (eds) Restoration of Endangered Species. Cambridge University Press, Cambridge, pp. 118-138.

Louda, S.M. (1998) Population growth of Rhinocyllus conicus (Coleoptera: Curculionidae) on two species of native thistles in prairie. Environmental Entomology 27, 834-841.

Louda, S.M. (2000a) Negative ecological effects of the musk thistle biological control agent, Rhinocyllus conicus. In: Follett, P.A. and Duan, J.J. (eds) Nontarget Effects of Biological Control. Kluwer Academic Publishers, Dordrecht, pp. 215-243.

Louda, S.M. (2000b) Rhinocyllus conicus - Insights to improve predictability and minimize risk of biological control of weeds. In: Spencer, N.R. and Nowierski, R. (eds) Proceedings of the 10th International Symposium on Biological Control of Weeds. 4-9 July 1999. Bozeman, Montana.

Louda, S.M. and Arnett, A.E. (2000) Predicting non-target ecological effects of biological control agents: evidence from Rhinocyllus conicus. In: Spencer, N.R. and Nowierski, R. (eds) Proceedings of the 10th International Symposium on Biological Control of Weeds. 4-9 July 1999, Bozeman, Montana. 
Louda, S.M. and McEachern, A.K. (1995) Insect damage to inflorescences of the threatened dune thistle Cirsium pitcheri. Bulletin of the Ecological Society of America 76,358 .

Louda, S.M. and Potvin, M.A. (1995) Effect of inflorescence-feeding insects in the demography and lifetime fitness of a native plant. Ecology 76, 229-245.

Louda, S.M., Potvin, M.A. and Collinge, S.K. (1990) Predispersal seed predation, postdispersal seed predation and competition in the recruitment of seedlings of a native thistle in sandhills prairie. American Midland Naturalist 124, 105-113.

Louda, S.M., Potvin, M.A. and Collinge, S.K. (1992) Role of seed-feeding insect, vertebrates, and plant competition in the limitation of a native thistle population. In: Menken, S.B.J., Visser, J.H. and Harrewijn, P. (eds) Proceedings of the 8th International Symposium on Insect-Plant Relationships. Kluwer Academic Publishers, Dordrecht, pp. 30-32.

Louda, S.M., Kendall, D., Connor, J. and Simberloff, D. (1997) Ecological effects of an insect introduced for the biological control of weeds. Science 277, 1088-1090.

Louda, S.M., Simberloff, D., Boettner, G., Connor, J., Kendall, D. and Arnett, A.E. (1998) Insights from data on the nontarget effects of the flowerhead weevil. Biocontrol News and Information 19, 70-71.

McCarty, M.K. (1978) The genus Carduus in the United States. In: Frick, K.E. (ed.) Biological Control of Thistles in the Genus Carduus in the United States. Progress Report, USDA-SEA, Stoneville, Mississippi, pp. 7-10.

McCarty, M.K. and Lamp, W.O. (1982) Effect of a weevil, Rhinocyllus conicus, on Musk Thistle (Carduus thoermeri) seed production. Weed Science 30, 136-140.

McCarty, M.K., Scifres, C.J. and Robison, L.R. (1967) A descriptive guide for major Nebraska thistles. University of Nebraska, Agricultural Experiment Station Bulletin 493, 1-24.

McEachern, A.K., Bowles, M.L. and Pavlovic, N.B. (1994) A metapopulation approach to Pitcher's thistle (Cirsium pitcheri) recovery in southern Lake Michigan sand dunes. In: Bowles, M.L. and Whelan, C.J. (eds) Restoration of Endangered Species. Cambridge University Press, Cambridge, pp. 194-218.

McEvoy, P.B. (1996) Host specificity and biological pest control. BioScience 46, 401-405.

Mellini, E. (1951) Insetti del Carduus nutans L. II Rhinocyllus conicus Fröl. e Larinus jaceae F. (Coleoptera Curculionidae). Bolletino Entomologica Bologna 18, 319-349.

Miller, M. and Aplet, G. (1993) Biological control: a little knowledge is a dangerous thing. Rutgers Law Review 45, 285-334.

New Zealand Government (1994) Biosecurity Act 1993. New Zealand Government, Wellington, New Zealand.

O'Brien, C.W. and Wibmer, G.J. (1982) Annotated checklist of the weevils (Curculionidae sensu lato) of North America, Central America, and the West Indies (Coleoptera: Curculionidae). Memoir No. 34. American Entomological Institute, Ann Arbor, Michigan.

Ownbey, G.B., Ravn, P.H. and Kyhos, D.W. (1975) Chromosome numbers of some North American species of the genus Cirsium. III. Western United States, Mexico, and Guatemala. Brittonia 27, 297-304.

Palmisano, S. and Fox, L.R. (1997) Effects of mammal and insect herbivory on population dynamics of a native Californian thistle, Cirsium occidentale. Oecologia $111,413-421$. 
Pavlovic, N.B., Bowles, M., Crispin, S.R., Gibson, T.C., Herman, K.D., Kavetsky, R.T., McEachern, A.K. and Penskar, M.R. (1992) Pitcher's thistle (Cirsium pitcheri) recovery plan. US Fish and Wildlife Service (Region 3), Department of the Interior, Minneapolis, Minnesota.

Pemberton, R.W. (1985a) Native plant considerations in the biological control of leafy spurge. In: Delfosse, E.S (ed.) Proceedings of the 6th International Symposium on Biological Control of Weeds. 19-25 August 1984, Agriculture Canada, Vancouver, pp. 365-390.

Pemberton, R.W. (1985b) Native weeds as candidates for biological control research. In: Delfosse, E.S (ed.) Proceedings of the 6th International Symposium on Biological Control of Weeds. 19-25 August 1984, Agriculture Canada, Vancouver, pp. $869-877$.

Peschken, D.P. (1984) Host range of Lema cyanella (Coleoptera: Chrysomelidae), a candidate for biocontrol of Canada thistle, and of four stenophagous foreign thistle insects in North America. Canadian Entomologist 116, 1377-1384.

Puttler, B., Long, S.H. and Peters, E.J. (1978) Establishment in Missouri of Rhinocyllus conicus for the biological control of musk thistle (Carduus nutans). Weed Science 26, 188-190.

Redfern, M. (1983) Insects and Thistles. Cambridge University Press, Cambridge.

Rees, N.E. (1977) Impact of Rhinocyllus conicus on thistles in southwestern Montana. Environmental Entomology 6, 839-842.

Rees, N.E. (1978) Interactions of Rhinocyllus conicus and thistles in the Gallatin Valley. In: Frick, K.E. (ed.) Biological Control of Thistles in the Genus Carduus in the United States. Progress Report, USDA-SEA, Stoneville, Mississippi, pp. 31-38.

Rees, N.E. (1982) Collecting, handling and releasing Rhinocyllus conicus, a biological control agent of musk thistle. Agriculture Handbook No. 579, USDA-ARS.

Rees, N.E. (1991) Biological control of thistles. In: James, L.J., Evans, J.O., Ralphs, M.H. and Child, R.D. (eds) Noxious Range Weeds. Westriew Press, Boulder, Colorado, pp. 264-273.

Root, R.B. (1973) Organization of a plant-arthropod association in simple and diverse habitats: the fauna of collards (Brassica oleracea). Ecological Monograph $43,95-124$.

Rowe, D.J., Kok, L.T. and Orcutt, D.M. (1985) Phytosterol requirement for propagation of Rhinocyllus conicus (Coleoptera: Curculionidae) on artificial diets. Journal of Entomological Science 20, 276-280.

Schaufuss, C. (1915) Calwer's Käferbuch. Einführung in die Kenntnis der Käfer Europea's, Vol. 2, pp. 1077-1079.

Secord, D. and Kareiva, P. (1996) Perils and pitfalls in the host specificity paradigm. BioScience 46, 448-453.

Shea, K. and Kelly, D. (1998) Estimating biocontrol agent impact with matrix models: Carduus nutans in New Zealand. Ecological Applications 8, 824-832.

Sheppard, A.W., Cullen, J.M., Aeschlimann, J.-P., Sagliocco, J.L. and Vitou, J. (1990) The importance of insect herbivores relative to other limiting factors on weed population dynamics: a case study of Carduus nutans. In: Delfosse, E.D. (ed.) Proceedings of the 7th International Symposium on Biological Control of Weeds, 6-11 March 1988, Istituto Sperimentale per la Patologia Vegetale (MAF), Rome, pp. 211-219. 
Sheppard, A.W., Cullen, J.M. and Aeschlimann, J.-P. (1994) Predispersal seed predation on Carduus nutans (Asteraceae) in southern Europe. Acta Oecologia $15,529-541$.

Shorthouse, J.D. and Lalonde, R.G. (1984) Structural damage by Rhinocyllus conicus (Coleoptera: Curculionidae) within the flowerheads of nodding thistle. Canadian Entomologist 116, 1335-1343.

Simberloff, D. (1981) Community effects of introduced species. In: Nitecki, T.H. (ed.) Biotic Crises in Ecological and Evolutionary Time. Academic Press, New York, pp. 53-81.

Simberloff, D. (1992) Conservation of pristine habitats and unintended effects of biological control. In: Kauffman, W.C. and Nechols, J.E. (eds) Selection Criteria and Ecological Consequences of Importing Natural Enemies. Entomological Society of America, Lanham, Maryland, pp. 103-117.

Simberloff, D. and Stiling, P (1996) How risky is biological control? Ecology 77, 1965-1974.

Simberloff, D. and Stiling, P. (1998) How risky is biological control? -- reply. Ecology $79,1834-1836$.

Smith, L.M. and Kok, L.K. (1983) Hyalomyodes triangulifer (Diptera: Tachinidae) parasitizes adults of Rhinocyllus conicus (Coleoptera: Curculionidae). Canadian Entomologist 115, 1533-1534.

Smith, L.M. and Kok, L.K. (1985) Influence of temperature on the development and mortality of immature Rhinocyllus conicus (Coleoptera: Curculionidae). Environmental Entomology 14, 629-633.

Smith, L.M., Ravlin, F.W., Kok, L.K. and May, W.T. (1984) Seasonal model of the interaction between Rhinocyllus conicus (Coleoptera: Curculionidae) and its weed host Carduus thoermeri (Campanulatae: Asteraceae). Environmental Entomology 13, 1417-1426.

Stanforth, L.M., Louda, S.M. and Bevill, R.L. (1997) Insect herbivory on juveniles of a threatened plant, Cirsium pitcheri, in relation to plant size, density and distribution. EcoScience 4, 57-66.

Surles, W.W. (1974) Native hymenopteran parasitoids attacking an introduced weevil, Rhinocyllus conicus in Virginia. Environmental Entomology 3, 1027-1028.

Surles, W.W. and Kok, L.T. (1977) Ovipositional preference and synchronization of Rhinocyllus conicus with Carduus nutans and C. acanthoides. Environmental Entomology 6, 222-224.

Surles, W.W. and Kok, L.T. (1978) Carduus thistle seed destruction by Rhinocyllus conicus. Journal of the Weed Science Society of America 26, 264-269.

Surles, W.W., Kok, L.T. and Pienkowski, R.L. (1974) Rhinocyllus conicus establishment for biocontrol of thistles in Virginia. Weed Science 22, 1-3.

Surles, W.W., Pienkowski, R.L. and Kok, L.T. (1975) Mortality of the immature stages of Rhinocyllus conicus, a thistle head weevil, in Virginia. Environmental Entomology 4, 371-372.

Thomas, M.B. and Willis, A.J. (1998) Biocontrol - risky but necessary? Trends in Ecology and Evolution 13, 325-329.

Turner, C.E. (1985) Conflicting interests and biological control of weeds. In: Delfosse, E.S. (ed.) Proceedings of the 6th International Symposium on Biological Control of Weeds. 19-25 August 1984, Agriculture Canada, Vancouver, pp. 203-225.

Turner, C.E. and Herr, J.C. (1996) Impact of Rhinocyllus conicus on a non-target, rare, native thistle (Cirsium fontinale) in California. In: Moran, V.C. and 
Hoffmann, J.H. (eds) Proceedings of the 9th International Symposium on Biological Control of Weeds, 19-26 January 1996. University of Cape Town, Stellenbosch, South Africa, p.103.

Turner, C.E., Pemberton, R.W. and Rosenthal, S.S. (1987) Host utilization of native Cirsium thistles (Asteraceae) by the introduced weevil Rhinocyllus conicus (Coleoptera: Curculionidae) in California. Environmental Entomology 16, 111-115.

Unruh, T.R. and Goeden, R.D. (1987) Electrophoresis helps to identify which race of the introduced weevil, Rhinocyllus conicus (Coleoptera: Curculionidae), has transferred to two native southern California thistles. Environmental Entomology $16,979-983$.

Withers, T., McFayden, R. and Marohasy, J. (2000) Importation protocols and risk assessment of weed biological control agents in Australia: the example of Carmenta nr. ithacae. In: Follett, P.A. and Duan, J.J. (eds) Nontarget Effects of Biological Control. Kluwer Academic Publishers, Dordrecht, pp. 195-214.

Woodburn, T.L. (1996) Interspecific competition between Rhinocyllus conicus and Urophora solstitialis, two biocontrol agents released in Australia against Carduus nutans. In: Moran, V.C. and Hoffmann, J.H. (eds) Proceedings of the 9th International Symposium on Biological Control of Weeds, 19-26 January 1996. University of Cape Town, Stellenbosch, South Africa, pp. 409-415.

Zwölfer, H. (1964) Larinus - Rhinocyllus. Progress Report 10, CIBC, Delémont, Switzerland.

Zwölfer, H. (1965) A list of phytophagous insects attacking wild Cynareae species in Europe. Progress Report 15, CIBC, Delémont, Switzerland.

Zwölfer, H..(1967) The host range, distribution, and life-history of Rhinocyllus conicus Fröl. (Col., Curculionidae). Progress Report 18, CIBC, Delémont, Switzerland.

Zwölfer, H. (1969) Additional feeding and oviposition tests with Rhinocyllus conicus Fröl. Progress Report 24, CIBC, Delémont, Switzerland.

Zwölfer, H. (1971) Competition and coexistence in phytophagous insects attacking the heads of Carduus nutans L. In: Dunn, P. (ed.) Proceedings of the 2 nd International Symposium on Biological Control of Weeds. October 1971, CAB International, Rome, pp. 74-81.

Zwölfer, H. (1978) Mechanismen und Ergebnisse der co-evolution von phytophagen und entomophagen insekten und höheren pflanzen. vröffentlichung naturwissenschaftlicher Verein Hamburg, Sonderband 2, 7-50.

Zwölfer, H. (1979) Strategies and counterstrategies in insect population systems competing for space and food in flowerheads and plant galls. Fortschitte der Zoologie 25, 331-353.

Zwölfer, H. (1988) Evolutionary and ecological relationships of the insect fauna of thistles. Annual Review of Entomology 33, 103-122.

Zwölfer, H. and Harris, P. (1984) Biology and host specificity of Rhinocyllus conicus (Fröl.) (Col., Curculionidae), a successful agent for biocontrol of the thistle, Carduus nutans L. Journal of Applied Entomology (Z. ang. Ent.) 97, 36-62.

Zwölfer, H. and Preiss, M. (1983) Host selection and oviposition behaviour in west-European ecotypes of Rhinocyllus conicus Fröl. (Col.: Curculionidae). Journal of Applied Entomology 95, 113-122. 